\title{
بناء السدود على الأنهار الدولية وفقًا لقواعد القانون الدولى العام
}

\author{
shel \\ د./ أكسرم مصطفى الزغبى مانى \\ مدرس القانون الدولى العام \\ كليتالحقوق - جامعت الزقازيق
}




\section{هقدهة}

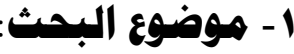

يعد نهر النيل الذي يجري في شمال شرق القارة الأفريقية وصولاً لمنتصفها

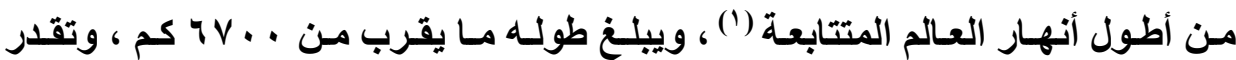

مساحة حوضه بنحو ج, ج مليون كيلومتر مربع ، ويمر بـول عديدة هي ( بوروندي،

ورواندا، وتنزانيا، وكينيا، وأوغندا، والكونغو الديمقراطية، وإريتريا، وأثيوبيا، وجنوب السودان(")، وشمال السودان، ومصر).(") وهنـاك عدة مصادر تمد نهر النيل بالمياه

بشكل رئيسي وهي الهضبة الأثيوبية ، والهضبة الاستوائية ، وحوض بحر الغزال . وتمد الهضبة الأثيوبية () نهر النيل عند أسوان بحوالي ه^\% من متوسط الإيراد

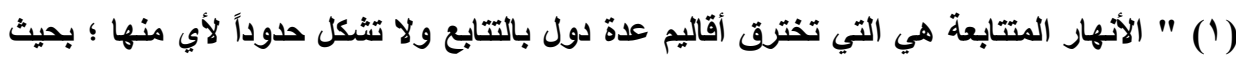

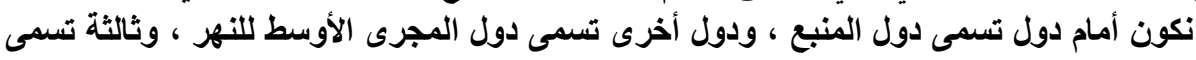

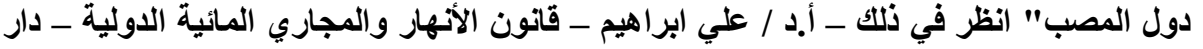

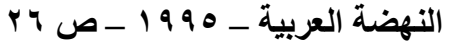

$\left.{ }^{2}\right)$ Rami okascha - water scarcity and regional security in the Nile basin. -

Grin publisher - 2013 - p 3 " Since south Sudan's secession in 2011 the Nile river is shared by eleven countries ( Egypt, Sudan, south Sudan, Ethiopia, Eritrea, Tanzania, Uganda, Burundi, Rwanda, D.R. Congo and Kenya )

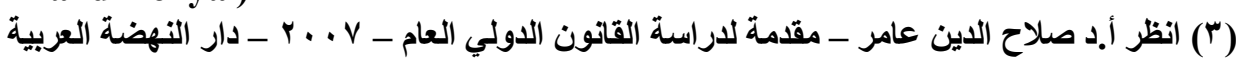

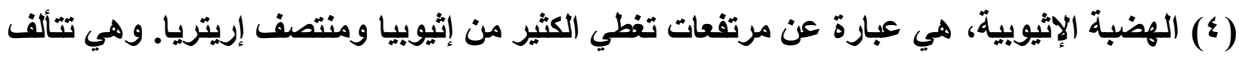

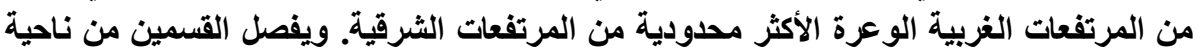

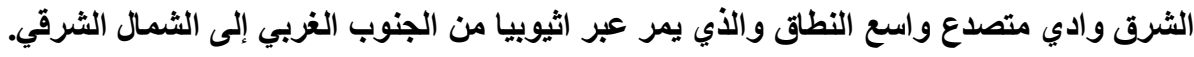
$=$ 
السنوي ( نحو V مليار متر مكعب سنوياً )، وتتجمع ميـاه الهضبة الإثيوبية من عدة أنهار وهي نهر السوباط ، والنيل الأزرق(')، ونهر عطبرة. أما الهضبة الاستوائية فهي

وتمتد المرتفعات الغربية من إريتريا وشمال منتصف إثيوبيا لحوض بحيرة "رودولف" في

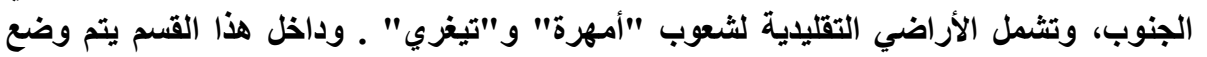

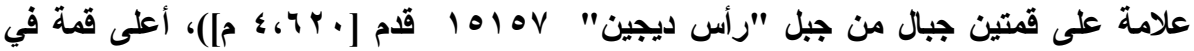

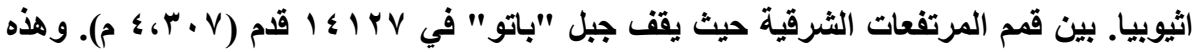

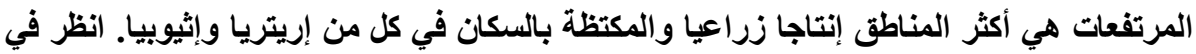

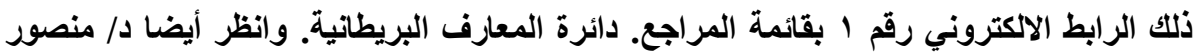

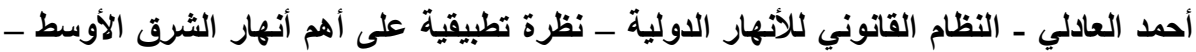

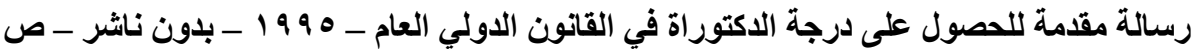

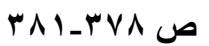

(1) Assef M. Melesse - Nile river " Hydrology, climate and water use " springer - 2011 - p 3-4" The blue Nile river basin is the main source of the Nile river with a drainage area of $324.530 \mathrm{Km}^{2}$ states that $(86 \%)$ of the annual flow of the Nile comes from the blue Nile river basin $(59 \%)$ from the Barro - akobo - sobat sub-system (14\%) and from the tekeze/ Atbara/ gash sub-system (13\%). The remaining (14\%) comes from the equatorial lakes after losses of evaporation in the sudd region and machar marshes. The upper blue Nile river basin is $176.000 \mathrm{Km}^{2}$ in area. The major tributaries of the blue Nile river in Ethiopia are gilgol abbay, megech, rib, Gumera, beshlo, woleka, jemma, guder, chemoga, fincha, dedessa, angor, Dura and beles. The upper blue Nile river basin is relatively wet when compared to the lower basin ( part of the blue Nile drainage basin Ethiopia until it joins the white Nile river ). Annual rainfall ranges from over $2000 \mathrm{~mm}$ in the southwest of the basin to a 1000 in the northeast." ..... see Diana Rizzolio Karyabwite " water sharing in the Nile river valley - unep/dewa/grid-Geneva - January March 1999 - January - June 2000 - Project gnv011: using Gis/remote sensing for the sustainable use of natural resources - p 26 " The water of $=$ 
أكثر المصادر انتظامساً في إمـداد النيل بالميـاه على مـدار العـام ؛ حيث يبلـغ المتوسط السنوي للمياه الواردة من الهضبة الاستوائية نحو بـ مليبار متر مكعب عند أسوان موزعة بين مصادر مختلفة ؛ هي بحيرة فكتوريـا ، وبحيرة كيوجـا ، وبحيرة ألبرت ، وبحر الجبل ، والنيل الأبيض. وتنتشر في حوض بحر الغزال عدة أنهار صغيرة تنبع من المناطق الجبلية بالسودان ، وجمهورية إفريقيا الوسطى ، ومجمل الإيراد السنوي لهذه الأنهار يبلـغ حوالي 10 مليـار متر مكعب في المتوسط ؛ يفقد منها الكثير في مناطق المستتقعات. (') ولعل بنـاء السدود على مجاري الأنهار الدولية موضوعُ بـات يشغل كثيراً مـن دول العـالم والمنظمـات الدوليـة والمجتمـع المـدني بـل والـرأي العـام الاولي؛ وبات ما تفعله أثيوبيا من سعيها في بناء عدة سدود على مجرى نهر النيل وينابيعه وأشـهرها سـد النهضة ؛ أمراً يزيــ من قلق المصريين حول مدى استتمرار منسوب المياه المتدفق من النهر أثناء بناء السد وبعد الاتتهاء من بنـاءه وبعد تشغيله وأثناء ملئ خزانه، ومدى احتمال أساسـات هذا السد لعوامل التآكل والتعريـة وأثر ذلك على انهياره وتسرب الماء منـه؛ للذا كـان من لازم الأمر أن أتعرض للقواعد القانونية الدولية التي تحكم بناء السدود على مجاري المياه الدولية، وخاصة الأنهار الدولية.

the Nile comes from two sources, the Equatorial Plateau and the Ethiopian Highlands, both of which receive large quantities of rain. The actual river came into being as a result of the interconnection of several independent basins and their integration into one river".

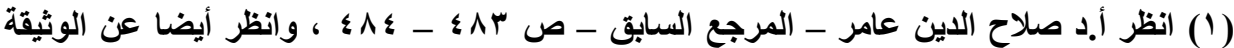

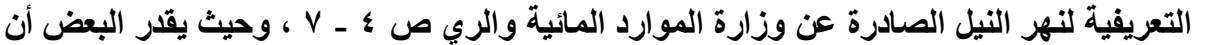

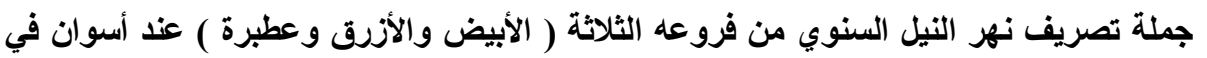

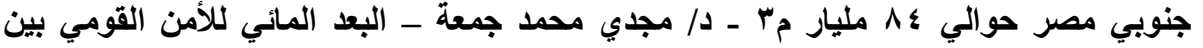

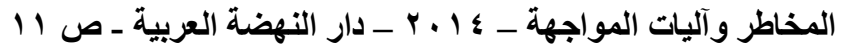




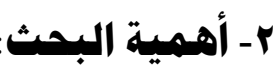

كان لبدء أثيوبيا في بنـاء سد النهضة كبير الأثر في بحث الفقهاء والعاملين بمجال القانون الدولي عن القواعد القانونية الدولية التي تحكم بنـاء السد والتي يمكن بها مواجهة أثيوبيا قانونيا بصفة خاصة كطرف في الأزمسة، ومواجهة المجتمع الدولي بصفة عامة إذا مـا قررت الإدارة المصرية السعي نحو اتخـاذ إجراعات وتدابير معينة تكفل حماية نهر النيل والحصة التي ترد لمصر منـه وفق قواعد القانون الدولي العام وبما لا يحمل الإدارة المصرية أية مسئولية دولية عن هذه الإجراعات والتدابير، فضلاً عن ذلك كان لابد من التوغل فنيا في بعض الأمور التي تعالج بنـاء السدود من الناحية الهندسية والفتيـة ومطابقة تلكت المعايير الفتيـة والتقنيـة مـع مـا يوافقها مـن القواعد القانونية كي يكون البحث متكاملا من حيث مراعاة الجوانب القانونية الدولية ومر اعاة الجواتب الفنية وفقا للمعايير الدولية.

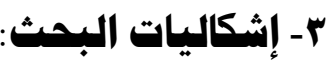

يتطرق البحث للإجابة عن تساؤلات عديدة يطرحها موضوع البحث ؛ أهمها ـ ما هي أهم الاتفاقات التي تنظم الانتفاع بمياه النيل؟ ومـا الفائدة التي تعود على مصر إذا استتدت لهذه الاتفاقات؟ وهل يجوز للدول منـابع النيل الاحتكام لمبدأ السجل النظيف للتصل من الالتزامات التاريخيـة تجـاه حصة مصر في ميـاه النيل أم أن الاتفاقات ذات الطابع العيني تمثل استثناء على مبدأ السجل النظيف؟ ومـا هـي نظريـات الفقه الدولي التي تناقش حقوق الدول النهرية في إجراء مشاريع على مجرى النهر الدولي؟ وهل تستند أثيوبيا لإحداها في بناءها لسد النهضة؟ وما هو أثر عدم تناسب حجم السد مـع معدل تدفق الماء؟ وهل هناك دور واضـح لمعهد القانون الدولي وقواعد هلسنكي في 
حماية حقوق الدول النهريةٌ وهل لمصر حق تـاريخي في ميـاه النيل ومـا هو الميـار المتبع في الاعتراف بمثل هذا الحق التاريخي، ومن أهم التساؤلات التي يثيرهـا البحث هو مدى جواز بناء السدود في دول المنبع ؟ ، ومـا هي القواعد القانونية الدولية التي تحكم بناء السدود وتثنغيلها بحيث لا يؤثر ذلك على منسوب وحصص المياه التي تذهب لاول المجرى الأوسط للنهر ودول المصب؛ وبمعنى آخر ماهي القواعد التي تحكم ملع خزانات السدود في بدايـة تشغيل السد وأثنـاء فترة التشغيل؟ ومـاهي القواعد الدولية التي تحكم التعويض عن الأضرار المترتبة عن بناء سد لا يتطابق مع المعايير الدولية ؟ وعلى إثر هذه التساؤلات جاء تقسيم الاراسة وفقا للخطة الآتية :

ك- هنهمج البمث:

اتبعت في هذا البحث منهجاً تأصيلياً تحليلياً ؛ وقد تجلى المنهج التأصيلي في رد الفروع إلى أصولها حيث تم البحث في الوثائق القنية والقانونية الصادرة عن المنظمات الاولية المعنية كتقرير لجنة السدود الدولية التي وضعت أولويات استراتيجية في بنـاء السدود الكبيرة ورددنـا هذه الأولويـات على الاتفاقية الدولية لقانون المجاري المائية الدولية واستخدامها في الأغراض غير الملاحية؛؛ كمـا اتبعنـا منهجاً تحليلياً يهدف إلى تفسير وتأويـل وتوضيح الاتفاقـات الدوليـة ومنـاهج الفقـهـ اللدولي وصولاً إلى النتـائج والتوصيات التي انتهت إليها الاراسة في هذا البحث.

0- خطة البمث: - 1

تتلخص خطة هذا البحث في تقسيم الدراسة إلى فصلين ، نعالج في الفصل الأول النظام القانوني الدولي للانتفاع بمياه نهر النيل ، ونتاقش في الفصل الثاني الأولويـات الاستر اتيجية في بناء السدود. 


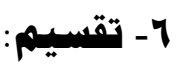
ندرس في هذا البحث ما يلي:
الفصل الأول: النظام القانوني الدولي للانتفاع بمياه نهر النيل.
المبحث الأول : الطبيعة القانونية لاتفاقات الانتفاع بمياه نهر النيل.
المبحث الثاني : الفقه الدولي وبناء سد النهضة الأثيوبي.
الفصل الثاني : الأولويات الاستراتيجية في بناء السدود
المبحث الأول : دور معهد القانون الدولي وقواعد هلسنكي في حماية حقوق

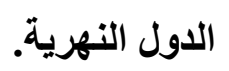

المبحث الثاني : احترام الحقوق التاريخية المكتسبة من قبيل الاقتسام العادل

(المعقول والمنصف) لمياه نهر النيل. 


\title{
الفصل الأول
}

النظام القانوني الدولي للانتفاع بمياه نهر النيل

\section{المبحث الأول \\ الطبيعة القانونية لاتفاقات الانتفاع بمياه نهر النيل}

\begin{abstract}
أولاً: الاتفاقات التي تنظم الانتفاع بمياه النيل
عقدت عدة اتفاقات لتنظيم الانتفاع بمياه النيل(') وأهمها وفقا للترتيب التاريخي

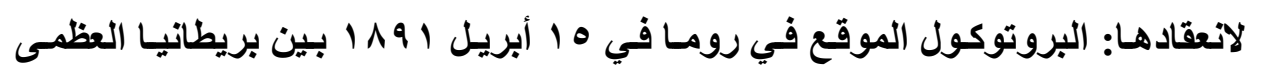

وإيطاليا والخاص بتعيين الحدود الفاصلة بين إريتريـا والسودان، والمعاهدات الموقعة لهوية

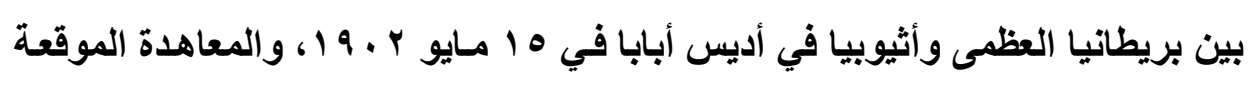

بين بريطانيا العظمى والكونغو في لندن في 9 مسايو 9 ، 9 ا ، والاتفـاق المنعقد بين

بريطانيا وفرنسا وإيطاليا في ب 1 ديسمبر 7 ، 9 ، ، والمعاهدة المنعقدة في الب يناير

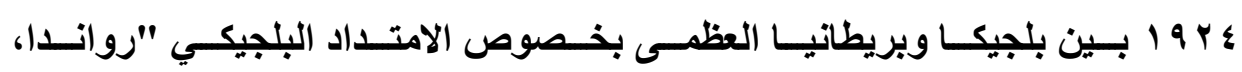

( ${ }^{1}$ Cari Meister - Nile river " The Nile river is the longest river in the world. It is 4.187 miles $(6.737 \mathrm{Km})$ long. The Nile has been important to plants, animals and people for thousands of years . millions of people have used its water for farming, drinking and transporting both people and goods"- 2010 - p 4 
وبوروندي"، والاتفاق المنعقد بين الولايـات المتحدة الأمريكية وبريطانيا العظمى في

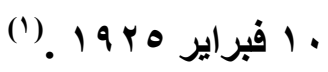

وتبادل المذكرات بين بريطانيا العظمى وإيطاليا في خـلال المدة مـا بين ؛ ا إلى

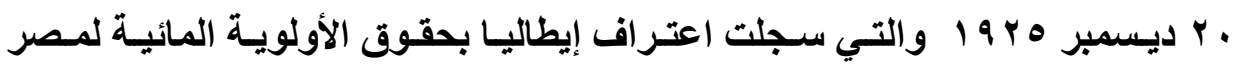
والسودان على النيل الأزرق وعلى النيل الأبيض وعلى روافدهما. (آ) والواضع من جميع هذه الاتفاقـات السابقة الاعتراف للـول التـي يمر بها نهـر النيـل بحقوقها في الانتفاع بمياه النيل، وذلك على عكس ما يراه البعض من أن مصر والسودان هم فقط

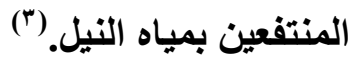

ويرى البعض أن من حق دول المنبع أن تمـارس على مجرى ميـاه النيل التي

تجري في إقليمها نفس الإنشاءات التي تقوم بها دول المصب أو دول المجرى الأوسط

(1) إن الهيكل العام لهذا الفرع من فروع القانون الدولي ما زال يرتكز على معاهدات ثلثائية علديدة

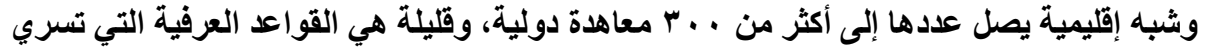

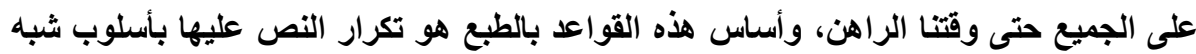

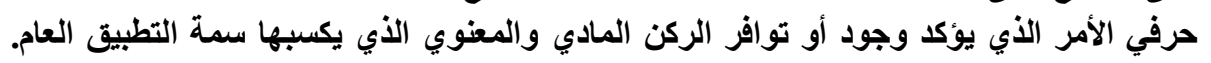

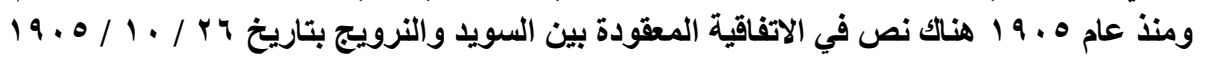

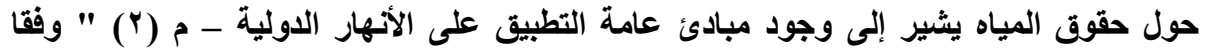

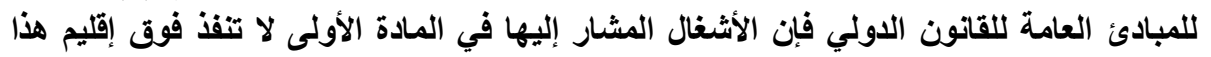

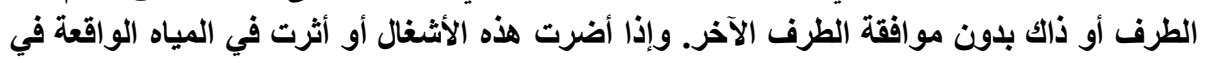

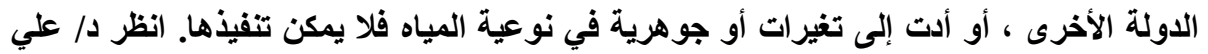

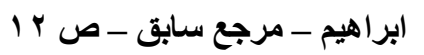

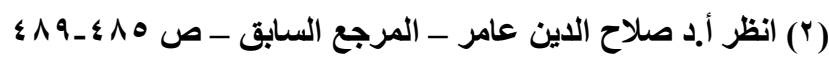

$\left(^{3}\right)$ Assef M. Melesse - Op.cit - p 408 " it is obvious to expect the complexity of dealing with sharing of the water in an equitable manner, what most think and know about the Nile is that the water is used solely by Egypt and Sudan." 
لنهر النيل تأسيسا على قاعدة المساواة في الحقوق النهرية وحق الاتتفـاع المتماثل(')، ولكتنـا نـرى هنـا ضـرورة التفرقة بين أوجـه الانتفـاع التـي تناسب دول المنبع وأوجـهـ الانتفـاع التـي تناسب دول المجرى الأوسـط للنهـر وأوجـه الانتفـاع التـي تناسب دول المصب؛ فمـا يناسب إحداها قد لا يناسب الأخرى. فبنـاء سـد على إقليم دولـة المصب وهي الدولة التي ينتهي إليها مجرى النهر لن يمنع المياه عن أحد وما سيكتنز من مياه سيكون مستخدما بشكل أساسي لفترة مؤقتة ثم يصرف إلى مصب النهر وإلا سيغمر الماء أرض دولة المصب ، على عكس بنـاء السد في دولة من دول المنبع لأن بنـاءه سيحجب الماء عن الدولة التالية لها في مجرى النهر سواء كانت دولة مصب أو إحدى دول المجرى الأوسط للنهر ؛ فضلا عن مخاطر انهيار السد إذا مـا ارتفع منسوب تدفق الماء داخل السد مما قد يؤدي إلى أضرار جسيمة بالدولة التي تليها في جريـان مجرى

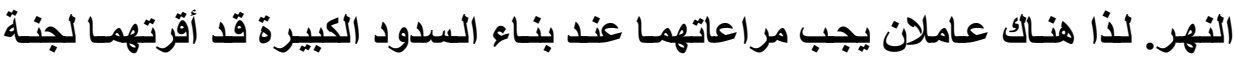
السدود الكبيرة كمبادئ إطارية:

1 - مشاريع السدود يتم الموافقة عليها عادة على أساس مسالي لميزانية استثمارية؛ وإذا تكلفت في نهايـة المطـاف أمسوال إضـافية فلابـد من العثور عليهـا وإيجـاد

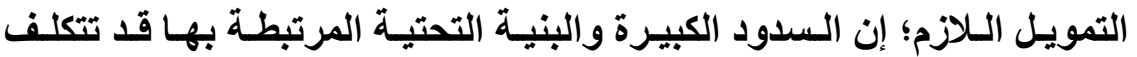
مليـارات اللدولارات، وهنـا كثيرا مـا تشتق تعريفة الرسـوم المقررة بنـاء على تقديرات التكـاليف ممـا يقوض الجدوى الماليـة للمشروع أو الجهود المبذولـة لاستعادة التكاليف.

( $)$ Bjorn lineman - Economy and transport in the Nile region - is the Nile a shaping element - Grin publisher - 2010 - p 1 
r ـ الجداول الزمنية لتنفيذ المشروع؛ حيث يوجد مؤشر ثاني ذو أهمية بالغة، وهو خلال مرحلة التنفيذ لمشروع بناء سد كبير؛ إلى أي مدى يتم إستيفاء الجداول الزمنية للمشروع، إذ أن التأخير في التاريخ الذي يجب أن ينتهي فيه المشروع يـؤدي إلسى زيـادة الفائسدة المتراكمـة على الأمـوال المقترضـة لأنسطة البنـاء والتأخير في الإيرادات المستحقة لمالك المشروع المنجز. (') و إذا نظرنا إلى كلا العاملين لوجدنا أن التركيز على التمويل و الجداول الزمنية للمشروع من أهم عوامل نجاح مشاريع السدود الكبيرة ، وهنـاك أيضا تبادل الخطابـات في V مايو 9 9 9 و بين رئيس مجلس الوزراء والمندوب السامي البريطاني ، والذي تضمن اعتر اف بريطانيا بحقوق مصر الطبيعية والتاريخية في مياه النيل ، وقد جاء في ختام خطاب اللورد "لويد" " أذكر دولتكم أن حكومة جلالة الملك سبق لها الاعتراف بحق مصر الطبيعي والتـاريخي في ميـاه النيل، وأقرر أن حكومـة جلالـة الملك تعتبر المحافظة على هذه الحقوق مبدأ أساسيا من مبـادئ السياسة البريطانية، كمـا أؤكد لاولتكم بطريقة قاطعة أن هذا المبدأ وتفصيلات هذا الاتفاق ستنفذ في كل وقت أيا كانت الظروف التي قد تطرأ فيما بعد."

كما قضت هذه الخطابات المتبادلة بأنه " بغير الاتفاق مع الحكومة المصرية لا يمكن القيام بأية أعمال بشأن الري أو بشأن توليد الطاقة على النيل أو على روافده أو على البحيرات التي ينبع منها إذا كاتت هذه الأعمال من شأنها إنقاص كمية المياه التي

(1) Dams and development A new framework for Decision-making : the report of the world commission on Dams - November 2000 - Earthscan publications Ltd, London and sterling, VA - p 40 - 41 
تصل إلى مصر ، وقضت أيضا بالاحتفـاظ بحقوق مصر في مراقبة مجرى النيل من

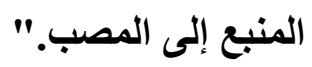

وهناك أيضا الاتفاق بين مصر والسودان بشأن إقامـة خزان جبل الأولياء الذي يتسع لثلاثة مليارات ونصف مليار متر مكب من المياه وغيرهـا الكثير من الاتفاقات. وفي أعقـاب اسـتقلال السودان عقدت مفاوضــات متعاقبـة بـين الحكومـة المـصرية والسودانية بشأن تنظيم الانتفاع بميـاه التيل بين الدولتين، وعندما عزمـت الحكومـة المصرية على إنشاء مشروع السد العالي تركزت المفاوضات على كيفية الانتفاع بكمية المياه الزائدة التي ستتنج عن إنشاء السد العسالي ، ورغبت الحكومـة السودانية في تعديل اتفاق سنة 9 \ 1 الإجحافها بحقوقها ، وتم التوصل لاتفاق ^ نوفمبر 9 9 1 بين الجمهورية العربية المتحدة (مصر) وبين السودان.

ويردد البعض أن هنـاك أمور لابد أن توضـع في الاعتبار عند النظر للانتفـاع بمياه النيل:

1 ـ مياه النيل ستكون محلاً للندرة، كنتيجة لضغوط التلوث البيئي، وتغير المناخ.

r ـ الدول المشاطئة لنهر النيل ستتنافس على هذه المياه لندرتها ومحدوديتها. (') وفي عـام ب9 9 ا وقع الرئيسان المصري حسني مبـارك ، والأثيوبي ميليس زيناوي اتفاق القاهرة وأثيوبيا لتنمية موارد مياه النيل وتعزيز مصالحهما الاقتصادية والسياسية، وفي أحد بنوده يتعهد الطرفان بالامتـاع عن أي نشاط يؤدي إلى إحداث ضرر بمصالح الطرف الآخر فيما يختص بمياه النيل، كما يعهد بالتشاور والتعاون في

(1) Assef M. Melesse - Op.cit - p 409 
المشروعات ذات الفائـدة المتبادلـة عمـلاً على زيـادة حجـم التـفقى وتقليلـل الفاقد مـن مياه نهر النيل في إطار خطط تنمية شـاملة ومتكاملة. كمـا اتفق الطرفان على إنشاء آليـة ملائمسة للمشاورات حول الموضوعات ذات الاهتمـام المشترك بمـا في ذلتك ميـاه النيل، وذلك للعمل مـن أجل السلام والاستقرار في المنطقـة، وتعهـ بالعمـل مـن أجل التوصل إلى إطار للتعاون بين دول حوض نهر النيل لتعزيز المصلحة المشتركة لتنمية حوض النهر، وهذا الاتفاق يعد اعترافا أثيوبيا صريحا بـالحقوق التاريخية والمكتسبة لمصر في تلك المياه ويمنع عن البلدين إلحـاق الأذى بـالطرف الآخر فيمـا يتعلق بميـاه (') (1) (1) ونخلص من الاتفاقات السابقة إلى أن الهذف الأعظم والمشترك لهذه الاتفاقات السابقة كلها ألا تجرى أية أعمال أو إجراعات على النهر إلا بعد التشاور ، وفي حدود الالتزام بكميات المياه التي تصل لكل دولة ؛ أي عدم الإضرار بأي دولة من دول النهر من جراء استخدامها لميـاه الحوض الموجودة بإقليمها ؛ خاصـة حقوق دول المصب مصر والسودان. (†) ومن ثم تعد هذه الاتفاقـات سنداً لمصر في الاحتفـاظ بحصتها في المياه المتدفقة على هضاب ومنـابع النيل الأبيض والأزرق وروافدهما. وأن بنـاء سد

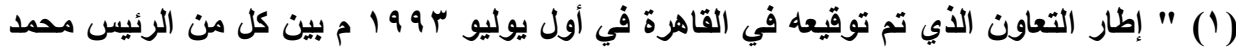

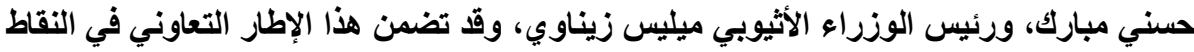

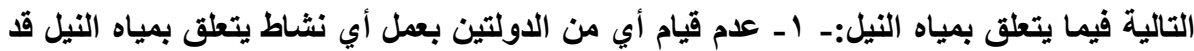

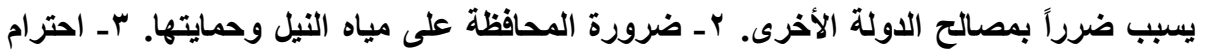

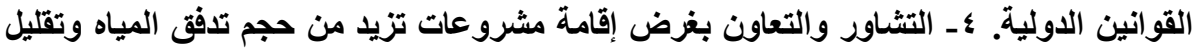

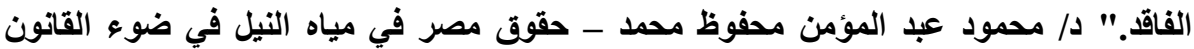

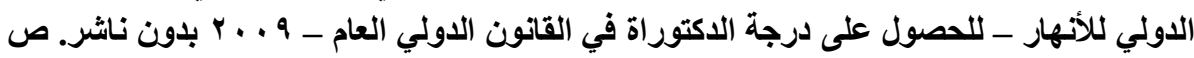


النهضة الأثيـوبي وغيره مـن السدود على روافـ منــابع نهر النيـل بغيـر التشـاور مـع دول المـصب وموافقتهـا أمسراً محظـورا وفقـا للقـانون الـدولي للمجـاري المائيـة الاولية.

ونظـراً لأنـهـه لــم تعــ الأنهـار الدوليـة تقتصر على الأنشطة الملاحيـة، وإنمــا أضحى لها دورُ غير ملاحي باعتبار هـا وحدة طبيعية واقتصادية واحدة فقد تضاعلت

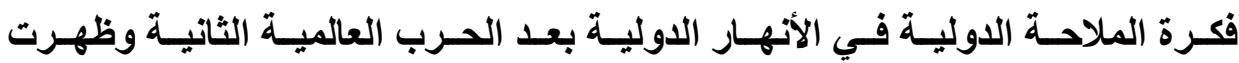

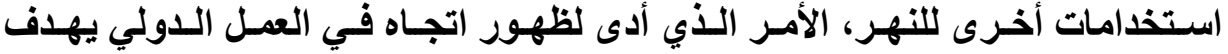
إلى جعل النهر وروافـده ومسباته وحدة مائيسة واحدة ذات طـابع اقتصادي شـامل، ويترتـب على ذلــك وجـوب التوزيـع العـادل لميـاه النهـر في غيـر شـئون الملاحـة والاستعمالات الزراعية والصناعية لهذه المياه بقصد تحقيق أكبر فائدة من تلك الثروة

(الطبيعية. (1)

\section{ثانيًا: اتفاقيات نهر النيل اتفاقيات ذات طابع عيني}

جرى العرف واستقرت الممارسـة الدولية على النظر نظرة خاصـة إلى طائفة معينة من المعاهدات الدولية التي تتعلق تعلقاً مباشراً بـالإقليم ويطلق عليها المعاهدات العينية أو الإقليمية ، حيث تواتر العمل الدولي على أن تلتزم الدولـة الخلف بمـاسبق للاولة السلف إبرامه من معاهدات؛ تتصل بالإقليم اتصالاً مباشراً مثل معاهدات الحدود ، والاتفاقات الدولية ، والمواصلات ، والأنهار الدولية، ونزع أو تقييد سـلاح إقليم من الأقاليم ، أو المعاهدات التي تتعلق بحياد أحد الأقاليم أو جزء منه.

(1 ) د د/ علي ابراهيم - مرجع سابق - ص 9 ب 
وقد حرصت اتفاقية فيينا لتوارث الدول بالنسبة للمعاهدات عام 9 لو على

تأكيا الوضع الخاص بالمعاهدات الدولية ذات الطابع العيني، وهي المعاهدات المتعلقة بالأقاليم بحيث لا تسمح بحال من الأحوال بأن يؤثر هذا التوارث الدولي على مثل هذه المعاهدات ، وهذا ما نصت عليه المـادة r ا من الاتفاقية لتنص على مـا استقر عليه العرف الدولي بشأن المعاهدات ذات الطابع العيني. (') ومسن ثـم فالاتفاقـات الاوليـة ذات الطـابع العينـي تأخــ حكم معاهـات الحـدود وأنظمتها ؛ فلا يجوز للاول الخلف أن تتنصل من الالتزامـات التي تضمنتها اتفاقـات دولية لها ذات الطابع وأبرمتها الدولة السلف ، ويستثنى من ذلك الاتفاقات الخاصـة بإقامة قواعد عسكرية أجنبية في الإقليم ، فلا تلتزم بها الدولـة الخلف. فلا يجوز إلغاء هذه المعاهدات العينية من جانب واحد ، إلا أن ذلك لا يحول دون التفاوض بشأن إبرام

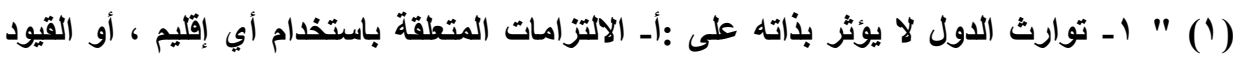

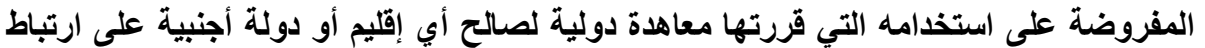

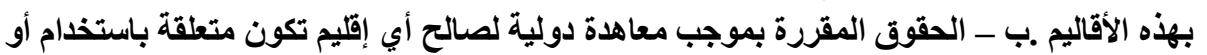

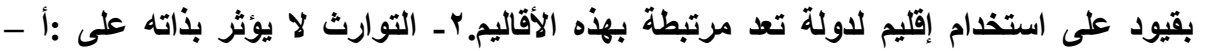

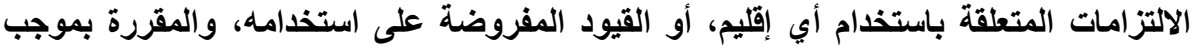

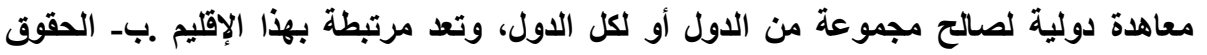

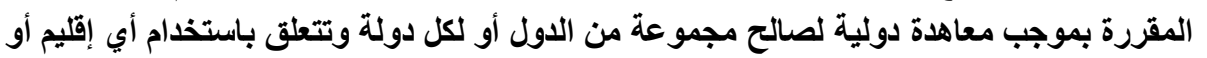

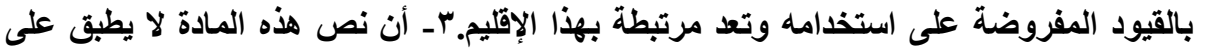

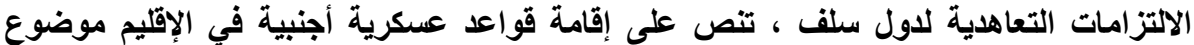

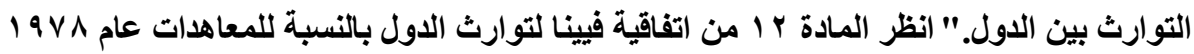

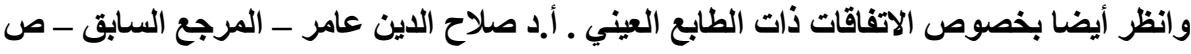


اتفاقات جديدة بقصد تطوير الانتفاع المشترك للنهر وزيـادة موارده المائية ، وتحسين

مجراه ، ومنع التلوث أو خفضه ومكافحته. (1)

وهنا رفعت الدول حديثة الاستقلال شعاراً مؤداه التحرر تمامـاً من أيـة التزامـات

تكون قد ارتبطت به الدول الاستعمارية ؛ بادئة حياتها بسجل نظيف مؤداه عدم التزامها بأية معاهدات تكون قد أبرمت باسم الاقليم من جانب الدولة المستعمرة. وعندما أثير الأمر في اتفاقية فيينا لعام 19 \ بشأن توارث الدول للمعاهدات الدولية ، تم التوصل لحل توفيقي بشأنه مفاده سريان المعاهدات المتعلقة بالحدود وأنظمتها والمعاهدات ذات الطـابع الاقليمسي أو العينـي ولا يستثنى من ذلكت إلا حالـة القواعد العسكرية الأجنبيـة. واعتمـدت الاتفاقيـة في المـادة 17 مبــأ السجل النظيـف أخـذة فـي الحسبان أيــا الاستثناعات الخاصة بالاتفاقات الدولية الخاصـة بالحدود أو الاقليمية أو التي هي ذات طابع عيني والاستثناء الوارد عليه الخاص بحالة القواعد العسكرية. وقد ذهبت محكمة العدل الدولية في النزاع بين المجر وسلوفاكيا بشأن مشروع Gabcikovo - Nagymaros الاتفاقـات المتعلقـة بالأنهـار الدوليـة سـواء فيمـا يتعلـق بالملاحـة النهريـة فيهـا ، أو باستخدام مياهها في غير شئون الملاحة هي من المعاهدات التي لا يجوز المساس بها نتيجة للتوارث الدولي، أي أنها من قبيل المعاهدات الدولية التي ترثها الدولـة الخلف عن الدولة السلف، ولا يجوز لها التحلل منها لأي سبب من الأسباب، بل ذهبت المحكمة إلى حسبان المادة r ا من اتفاقية فييـا - بشأن توارث الدول للمعاهدات الدولية لعام 
I QV^ بمثابة قاعدة من قواعد العرف الدولي، أي أنها ملزمسة لجميع الدول، لا يجوز

التحلل منها أو الخروج عليها. (')

ونخلص مما سبق إلى أنه لا يجوز لأثيوبيا الاحتكام لمبدأ السجل النظيف للتنصل

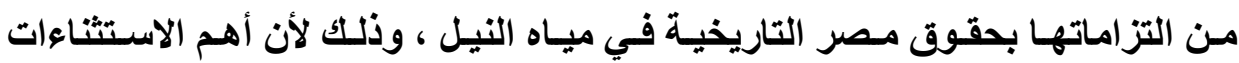
الواردة على مبدأ السجل النظيف هي احترام الاتفاقات ذات الطابع العيني. 


\section{المبحث الثاني}

\section{الفقه الدولي وبناء سد النهضة الأثيوبي}

\section{أولاً: نظرية هارهون}

وفقـا لهـذه النظريـة (1) تمـارس الدولـة سـيادتها الإقليميـة المطلقة وسـلطتها اللامحدودة على الجزء الواقع في إقليمها من المجرى المائي الدولي؛ أياً كانت النتائج أو الأضرار المترتبة على هذه الممارسة والتي تصيب الدول الأخرى المستفيدة من هذا النهر أو المجرى. (†)وقد اعتمدت أثيوبيا في بعض مزاعمها حول النيل الأزرق على

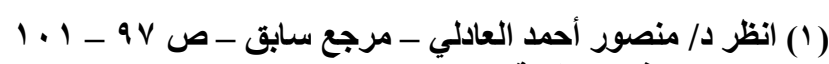

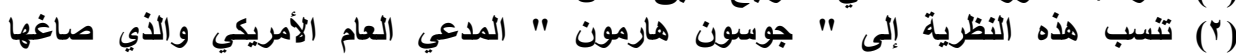

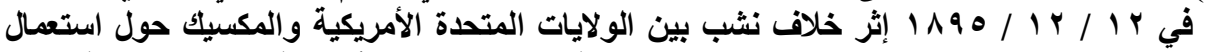

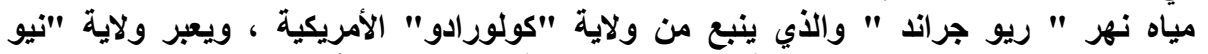

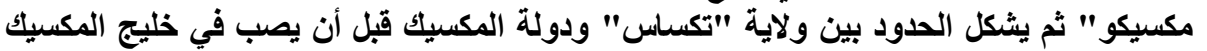

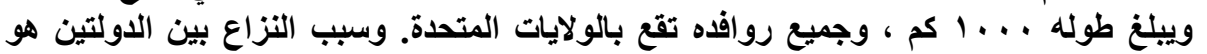

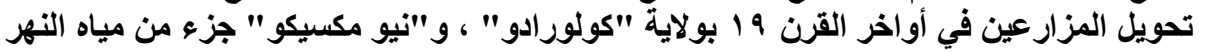

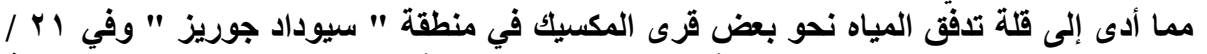

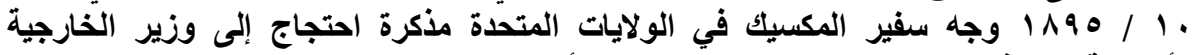

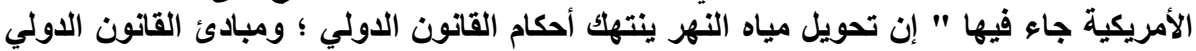

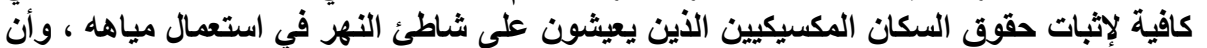

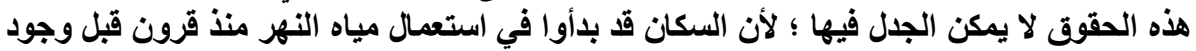

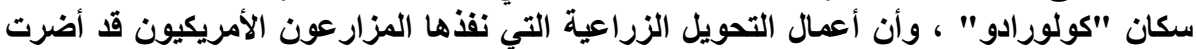

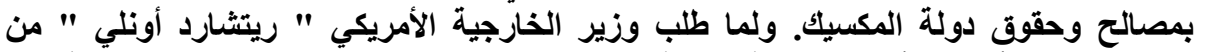

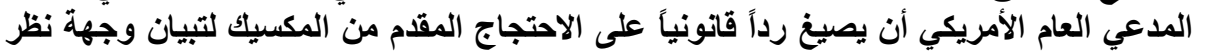

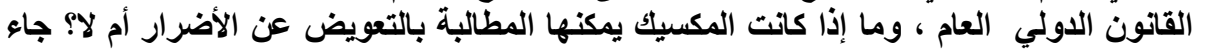

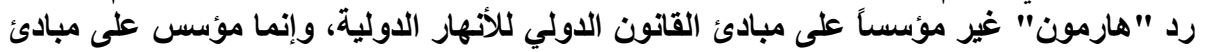

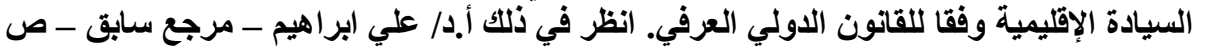


فقـه هـارمون في السيادة المطلقة ، وقد فنــ فقهـاء القـانون اللدولي هذا الفقـه وهذه النظرية، واعترف بحق كل طرف في استعمال الميـاه الموجودة فوق أرضـه كمـا يحلو له، بشرط ألا يعتدي على حق الطرف الآخر أو يسبب له أضراراً.

\section{ثانيًا: نظرية التكاهل الاقليسمي المطلق أو الحقوق النهرية}

تعني هذه النظرية أن دولة المصب خاصة تلك التي يوجد أو يمر فيها الجزء أو القطاع الأخير من النهر ؛ مثل مصر بالنسبة لنهر النيل من حقها أن تطلب من الدول النهرية الأخرى أي دول المنبع نفس الكمية من المياه وينفس الجودة التي يوفرهـا لها النهر بثكل طبيعي ؛ ومفـاد ذلك أن الجزء الذي يمر عندها يعتبر متكاملاً مـع الجزء الذي هو المنبع ؛ فالمساء الذي يفيض فوق إقليم دولـة المنبع أو الذي يتم استقباله يفترض أنه يخص دول المصب ، ومن ثم فِان أي تعديل لمجرى المساء في دول المنبع يعد خرقاً لسلامة إقليم دولة المصب. ولذلك يحق لكل دولة من دول المصب الاعتراض أو نسف أي استعمال لمجرى النهر غير مرغوب فيه لاولة المصب ؛ حتى ولو كـان مرغوب فيهه من دولـة المنبع ؛ متى كان من شأنه أن يؤدي إلى إحداث تغييرات في مجرى النهر أو في كمية الميـاه أو نوعيتها ـ وأيضاً هذه النظرية تجحف بحق دول المنبع ، وتصب دومـاً في مصلحة دول المصب. (1) 


\section{ثالثًا: نظرية الاستعمال العادل أو السيادة الإقليسية المقيدة}

تأسست هذه النظريـة (') على مبدأ حسن الجوار ببين الدول النهريـة ، والذي

يسمح بإقامـة علاقـات قوامها المصلحة المشتركة في استعمال ميـاه النهر ؛ حيث أن هناك فوائد ومزايا مشتركة لا يجوز أن تستأثر بها دولة بمفردها ؛ فالدول الموجودة في حوض نهري واحد تجمعها مصلحة واحدة ، ومن ثم يجب تقسيم وتوزيع ثروات النهر بطريقة مفيدة للجميع ، وهي نظريـة ترتبط ارتباطا وثيقاً بفكرة السيادة المقيدة التي تفرض على كل دولة واجبـات معينة ، وأهمها عدم جواز استعمال إقليمها أو الجزء الذي يمر بأرضها بطريقة تؤدي إلى إلحاق ضرر جسيم بمصالح الدول النهرية الأخرى الواقعة عن المنبع أو عن المصب.

وتعد نظرية السيادة الإقليمية المقيدة أو التوزيع العـادل لميـاه المجرى المسائي

الدولي هي النظرية السائدة اليوم في الفقه والعمل والقضاء الدولي، وقد أحسنت لجنة تدوين القانون الدولي عملاً عندما قنتت أفكار ومبادئ هذه النظرية في مشروعها حول قانون استخدام المجاري المائية الدولي في غير شئون الملاحة. تعنى هذه النظريـة أن كل دولة نهرية لها حق فوق إقليمها في جزء أو في نصيب معقول ومنصف في استغلال او استعمال ميـاه النهر والفوائـــ والمزايـا المستمدة منـه بشرط ألا يترتب على هذا الاستغلال أي ضرر ملموس أو جوهري بمصالح جيرانها الذين يتقاسمون معها فوائد هذا النهر، لأنها ذات سيادة مقيدة وليست مطلقة، وبناء عليه فلها حق استعمال النهر جرت الدولي أو الجزء منه الخاضع للسيادة المقيدة بطريقة عادلة ومعقولة وعدم تجاوزهـا 
حقها في الاستعمال المعقول وعدم حرمـان الدول النهريـة الأخرى من حقوقها العادلـة

والمنصفة في مياه النهر. (')

\section{رابعًا: نظرية المورد الطبيعي المشترك}

تقوم هذه النظريـة (†) على مبدأ الانتفـاع العـادل والاقتـسام المنصف لمنـافع

النهر، فلا يجوز لأية دولة من الدول المشاطئة للنهر الدولي أن تتصرف انفرادياً بشكل يلحق الضرر بدول مجرى النهر سواء كانت دول المجرى من دول المنبع أو من دول المصب. تأسيساً على المبدأ سـالف الذكر. ومن ثم تتعاون الدول المشتركة في النهر الدولي من خـلال الإدارة المشتركة لمنـافع النهر بغيـة تحسين البيئة النهريـة وتطوير استخدام النهر وصيانته تحقيقا للنفع المشترك. ويقع على الدولـة النهريـة عبء حمايـة البيئة النهرية ومنع تلويثها باعتبار النهر موردا طبيعيا مشتركاً ببين الدول المشاطئة

ويتزامن مع ذلك الأخذ في الاعتبار أن كثافة الأنشطة النهريـة وتعددها وندرة

المياه العذبـة أدى إلى صراعات ومنازعـات حول الحقوق المائية ممـا أدى إلى ظهور

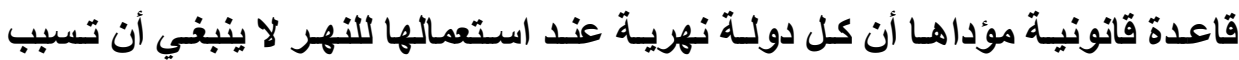
أضراراً هامـة لدولـة أخرى من دول المجرى المـائي الدولي، وضرورة أن تحصل كل دولة على حصة مناسبة من المياه تتفق مع حاجاتها ( أي التوزيع العادل للحصص المائيـة )، وأن المجرى المسائي الدولي يعد وحدة طبيعية واحدة وكـلا لا يتجزأ رغم 
مروره بأقاليم دول مختلفة؛ لذا يجب أن تكون إدارته تعاونية أو بالتفـاهم المشترك بين

الاول النهرية صاحبة المصلحة. (')

ويتفرع عن هذه النظرية التزام آخر مفاده أن الدول النهرية التي تريد تنفيذ أو

إقامة مشروعات على جزء النهر الأي يمر بأرضها أو تريد تغيير النظام القائم لشبكة الميـاه الدوليـة، والتي تتعـارض مـع أهداف ومـصالح اللدول النهريـة الأخرى أو تضر بحقوقها أو تنقص في حصتها العادلة والمنصفة في الاستفادة من المياه، عليها واجب منـع الدولـة المعرضـة للضرر فرصـة الاعتراض والرد على هذه المشروعات المراد تنفيذها على شبكة المياه الدولية. وإذا ما اعترضت الدولة الثانية، وبحسن نية، وأبلات رغبتها في التوصل إلى حل سريع وعادل من خـلال الوسـائل السلمية لفض المنازعـات والمنصوص عليها في المادة (Tr) من ميثاق الأمم المتحدة وجب على الدولة صـاحبة المشروع أن تتوقف عن تنفيذه إلى أن يتم الوصول إلى حل. () وقد تحقق إجمـاع على وجود عدة مبادئ أساسية تنظم الحقوق والواجبات للاول التي تثترك في مجرى مسائي

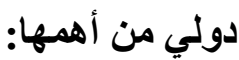

\section{ا - هبدأ العدالة في توزيع المياه والانتفاع المشترك}

انعقد الإجمـاع على مبدأ إنتفـاع دول المجرى المـائي اللدولي بطريقـة منصفة ومعقولة، وتشمل هذه المشاركة حق الانتفـاع بـالمجرى المسائي الدولي والتزام مفـاده التعاون على حماية المجرى المائي الدولي وتطويره وتنميته للأجبـال القادمـة. فالدول النهرية لها حصة من الميـاه والاستعمال المقيد لشبكة الميـاه الدولية على أسـاس من

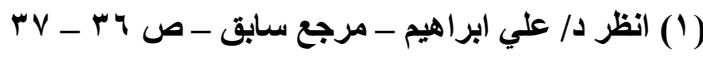

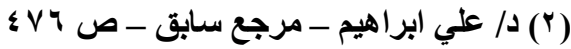


العدل والإنصاف، و هنا لتقرير ما هو عادل ومنصف ومعقول يجب أن يؤخذ في الاعتبار

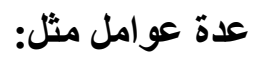

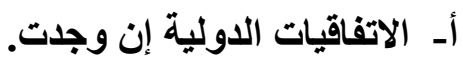

$$
\text { جـ أحكام وقرارات المحاكم ولجان التحكيم. }
$$

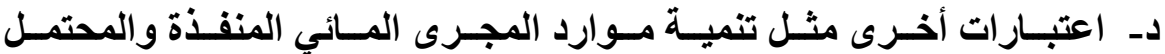
تنفيذها في المتتقبل ، وتنوع استعمالات المياه وعدد السكان ووجود مصادر

$$
\text { (1) بلفيلة في }
$$

وقد جاء إعلان استكهولم الصادر عن مؤتمر الأمم المتحدة للبيئة الإنسانية في المبدأ رقم ؛ ؟ من مبادئ الإعلان موضحاً الآتي " إن القضايا الدولية المتعلقة بحماية وتطوير البيئة يجب أن تعالج بروح من التعاون من قبل جميع الدول الكبرى والصغرى على السواء. وعلى قدم المساواة عبر القتوات الثنائية أو متعددة الأطراف أو بواسطة أي وسيلة أخرى مناسبة هو أمر حيوي من أجل الحد بفاعلية ومنع وتخفيض وإزالة التعلديات على البيئة الناجمـة عن الممارسـات في شتى المجالات ـوفي إطار احترام السيادة والمصالح لجميع الدول ". قد أكد القضاء الدولي في قضية "فورتمبرج " "بروسيا" ضد "بادن" عام V I I بشأن الخلاف حول مياه نهر الدانوب على مبدأ الاتتفاع العـادل والاقتسام المنصف لميـاه النهر؛ حيث جـاء حكم المحكمـة القدراليـة الألمانية " أن كل دولة عند استفلالها لمياه النهر فوق أراضيها والذي تملكه بالاشتراك 
مع غيرها من الدول، تخضع لقيود مستمدة من المبادئ العامـة للقانون الدولي، وهذه القيود تمنعها من إلحاق الضرر بحقوق عضو آخر من أعضاء الجماعة الدولية؛؛ إن أي دولة ليس لها الحق في إلحاق ضرر خطيز بمصالح دولة أخرى بواسطة الاستغلال الأي توفره مياه النهر الطبيعي". (1) r- هبدأ الاستهمهال البزيs ومفـاده الالتزام بضرورة الاستعمال البريء لميـاه الأنهار الدوليـة مـن جانب الدول المشاطئة للنهر، وهذا هو فحوى الاستعمال غير الضار بالدول الأخرى على مجرى النهر؛ ويعتبر استعمال الدولة المشاطئة للنهر الدولي بريئا إذا لم يكن من شـأن استخدام تلكك الاولـة للنهر محدثاً لتعديلات ضسارة في مركز الدولة الأخرى من حيث الاستعمال والانتفاع بمياه النهر الدولي. فما هو الفارق بين الضرر الملموس والضرر

\section{* الفارق بين الضرر الملهوس والضرر العادي}

إن تفــادي جميع الأضـرار أمـرُ مستحيلُ عمليـاً، فقاعدة عدم الإضـرار بـالغير، والاستعمال البرئ لمياه النهر الدولي لا تستبعد جميع الأضرار، وإنما المحظور هنـا هو الضرر الملموس الذي يتحقق منـه وفق معايير موضوعية، بحيث يثبت أن من شـأن الاستعمال إحداث أثر مؤذي هام على الصحة العامة أو على الأقل يصعب الاستفادة من مياه النهر بشكل ميسر أو معقول داخل الدولة التي أصـابها الضرر. فالضرر الملموس إذا ليس هو الضرر العادي التافه أو الذي لا يؤثر في كم ونوع المياه ومدى جودتها،

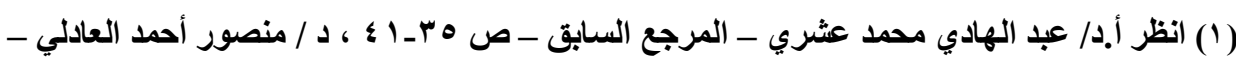


والـــي لا يـشكل خطـورة علـى اسـتغلال ميــاه النهـر فـي دول المجـرى الأوسـط أو دول المـصب. أي الـضرر الملمـوس أو الجـوهري هـو الـــي تتعــز معـه معيشة السكان على ضفاف النهر مثل قطع الميـاه كلياً أو جزئياً أو تلويث النهر بشكل حاد وخطير.

فالضرر الملموس أو الجوهري يرتب المسئولية الدوليـة للاولة النهريـة التي أحلثته، والأضـرار العاديـة أو التافهة تتسامـح فيها اللدول عـادة وفقا لمقتضيات حق هق الجوار. ويصعب وضع معيار حاسم واضـح موضوعي للتفرقة بين الضرر الجوهري والضرر العادي بحيث يشكل قاعدة عامة تنطبق على جميع استعمالات المجاري المائية الدولية؛ لذا فالعبرة بظروف كل حالة على حدة. (') ولكن هل يمكن الاتفاق على إزالة الأضرار الناجمة عن الاستعمال العادل لمياه المجرى المائي الدولي؟ أفصحت المادة r/V من اتفاقية استخدام المجاري المائية الدولية في الأغراض غير الملاحية لعام 199 19 عن حلين بصدد الإجابة على هذا التساؤل:الأول:- حالة ما إذا كان هناتك اتفاق مسبق بين الدول المعنية، وهنا تطبق أحكام الاتفاق لعلاج الموقف وتنتهي المشكلة لأن الاتفاق معه سلفا ولا يحتاج سوى تطبيقه .

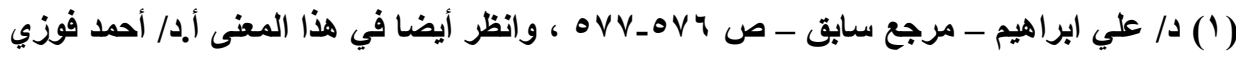

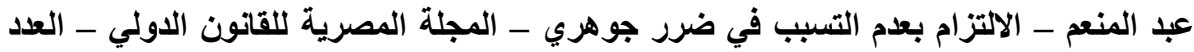

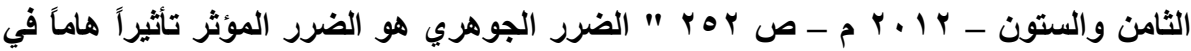

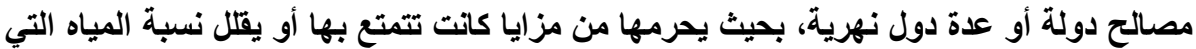

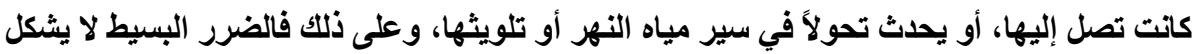

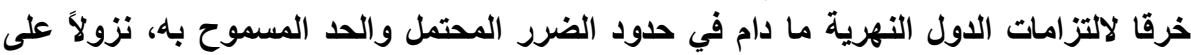

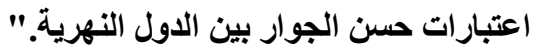


الثاني:- حالة عدم وجود اتفاق مسبق بين الدول، وهنا تقوم الدولة التي صدر عنها وعن استعمالها الضرر الذي أصساب دولة أخرى بالدخول في مشاورات مـع دول المجرى الأخرى بخصوص" الإجراء الـذي نجـم عنـهـ الـضرر ، ومسـألكة التعـديلات الخاصـة التي يجب إدخالهـا على الاستعمال العـادي بقـصد إزالـة الـضرر وتخفيفـه، والتعويضات إن كان للتك مقتضى.

وفي الحكم الصادر عن محكمة العدل الدولية في الاختصاص بقضية المصايد

لعام \& \9 ابين بريطانيا وإيسلندا حيث قررت المحكمة: " إن الطريق الأقرب إلى حل النـزاع هو طريـق المفاوضـات، وموضـوعه وهلفه يجب أن يحيط بحقوق ومسصالح الأطراف ، والالتزام بالـاخول في المفاوضـات هنـا ينبع مـن طبيعة الحقوق المتقابلـة للطرفين، ويتفق مـع مبـادئ وأحكـام ميثاق الأمسم المتحدة المتعلقة بحل المنازعـات

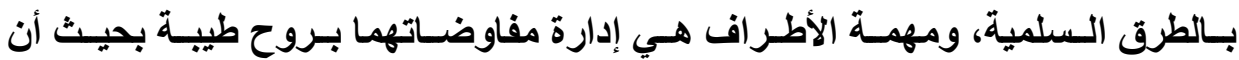
كل منهمــا يلتزم وبحسن نيـة بالأخـذ في الاعتبـار حقوق الطرف الآخر، واعتبـارات الموقف المحلي، أخذاً في الاعتبار مصالح الدول الأخرى التي لها حقوق ثابتة لا جدل في ذلك. (1) وقد أقرت لجنـة القـانون الدولي عـام 909 19بدأ الاستعمال البريء ورتبت المسئولية الدولية على عاتق كل دولـة ترتكب من الأعمـال العامـة أو الخاصـة مـا من شأنه التعديل في نظام مياه النهر الدولي بما يضر بالدول الأخرى، وعلى كل دولة تريـ القيام بعدل مـن ذلك القبيل أن تتشاور مسبقا مـع غيرهـا من الدول المشاطئة للنهر الدولي.

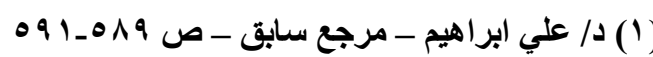




\section{r- بـدأ الاستعمشال المتكاهل للأنهار الدولية}

يقصد بالاستعمال المتكامل للأنهار الدولية النظر إلى حوض مجرى النهر كوحدة واحدة لكل الدول النهرية يحق لهم الاستفادة منـه ككل، ومـن ثم لابـا أن تتعـاون الدول النهرية بقدر الإمكان بغية كفالة الاستغلال الكامل للموارد المائية، ولهـا الغرض على هذه الدول التي يجري بها النهر الدولي اعتبار حوض النهر الدولي كلُ متكامل لا يـأتي استخدام على حساب أي استخدام آخر. (') فلا يأتي استخدام المجرى النهري الدولي لتوليد الطاقة الكهربائية من خلال بناء السدود أو تحويل جزء من مجرى النهر الدولي أو كله على حساب استخدام النهر في الملاحة النهرية سواء للاول النهرية أو للاول غير النهرية.

ونخلص مما سبق إلى وجود عدة مبادئ أساسية تنظم الحقوق والواجبات التي

$$
\text { يجب على الدول الواقعة على نهر دولي مشترك احترامها وهي: }
$$

ـ التوزيع العادل لمياه النهر والاقتسام المنصف لها. ويقع عبء إثبات أن الاستخدام عادل ومعقول على عاتق الدولة التي نجم عن استعمالها الضرر الذي أصاب الدول النهريـة الأخرى، حيـث أن الاسـتعمال عـادل ومعقول إلى أن يثبت العكس فلكل الأطر اف مصالح تسعى لحمايتها من خلال استعمالها للمجرى المائي الدولي وهنـا لا يؤخذ في الاعتبار فقط الضرر الواقع على الدولة المجاورة، وإنمـا أيضا العلاقة 
أو الرابطة بين الفائدة المتحصل عليها للاولة التي قامت بالاستعمال والضرر الأي

$$
\text { أصاب دولة أخرى. (') - (اول) }
$$

ـ لا يجوز لدولة يمر النهر الدولي بأراضيها أن ترتكب أي عمل من شـأنه الإضرار

$$
\text { بحقوق الدول النهرية الأخرى على مجرى النهر الدولي. }
$$

ـ عدم إجراء أي تحويل في مجرى النهر أو إقامـة سدود عليه تنتقص من حصة كل دولة نهرية على المجرى المائي للنهر الدولي قد حصلت عليها وفقا لاتفاقية دولية سابقة أو وفقا لعرف جرى اتباعه ما لم يتم الاتفاق على غير ذلك بين تلك

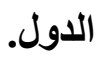

ـ على كل دولة نهرية تقع على شاطئ النهر الدولي أن تتخذ ما يكفل من الإجراءات التي تحول دون تلويث التهر أو الإضرار به مما يقلل من إمكانية الانتفاع بـه على المدى القصير للجيل الحالي أو على المدى الطويل للاجيال القادمـة؛ ويجب عليها أن تعترض على غيرهـا من الدول التـي قد تـؤدي بتصرفاتها إلى تلويـث النهر الاولي.

- إن أيـة دولـة تخـالف مبـأ الاسـتعمال البريء للنهر الـدولي ؛ تتحمـل المسئولية

$$
\text { الاولية عما سببته من أضرار. }
$$

ـ ضرورة التعاون بين الدول الواقعة على مجرى النهر الدولي في تنميـة موارده

وتعظيم الاستفادة من كل استخداماته كوحدة واحدة. (؟)

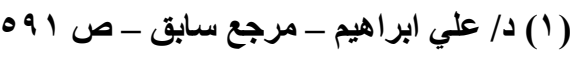

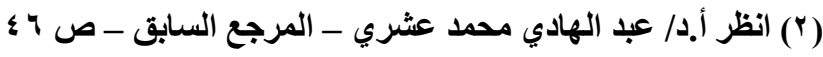


ومما سبق نخلص إلى أن مجرى النهر الدولي هو مجرى مشترك لا يجوز لأحد الانتفاع به دون مراعاة حقوق الآخرين ممن لهم حق الانتفاع به على أسـاس الاشتراك في الإدارة والاشتراك في المنـافع، لذا يجب مراعـاة المبادئ سـالفة الذكر حينمـا يتم اسـتخدام المجـاري المائيـة الدوليـة، وهنـا يثـار التسـاؤل حـول كيفيـة تقاســم المـوارد الطبيعية وهذا ما نعالجه في المطلب التالي.

\section{الإطلب الثاني}

\section{تقاسم الموارد الطبيعية}

\section{أولاً : هفهوم تقاسم الموارد الطبيعية}

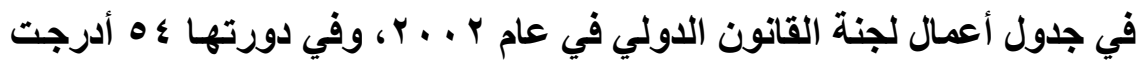
في برنامج عملها موضوع " تقاسـم الموارد الطبيعية "، ولكن هنـاك فرق في طبيعة الموارد المشتركة ؛ حيث يختلف النظام القانوني للمياه العابرة للحدود أو المياه الدولية عن الموارد الطبيعية المشتركة الأخرى مثل البترول ـ فلا تستطيع دولة واحدة بما فيها دولة المنبع أن تدعي السيادة على المياه وإن كان لها بالقطع السيادة على جزء النهر نفسه باعتباره جزء من ترابها الوطني. كما أنها لا تسنطيع أن تتصرف في المياه بالبيع أو خلافه لغيرها من الاول التي لا تثترك في الحوض المسائي. على عكس حق الدولة في السيادة التامـة على البترول في أراضيها وغيره من المعادن وحق التصرف فيه بالبيع أو الاستهلاك استناداً لحق الملكية. ويقصد بالمياه الدولية " هي تلكك المياه التي 
تتصل فيما بينها في حوض طبيعي واحد منى امتد أي جزء من هذه المياه داخل دولتين

(1) (أو أكثر.

\section{ثانيًاً : المورد الطبيعي المشترك والهق التاريخي}

كاتت فكرة المورد الطبيعي المشترك من بين التوجيهات التي أصدرتها الحكومـة

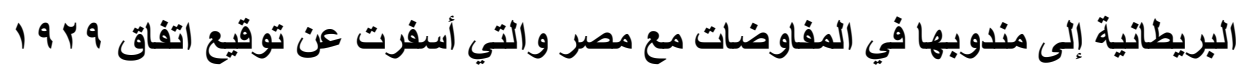
المتعلق بالنيل ، والذي أكد حقوق مصر الطبيعية والتاريخيـة في ميـاه النيل. وقد ذكر مندوب دولة زائير في لجنة القانون الدولي أنه وفقاً للتقاليد الأفريقية لا يمكن منع الماء عن ظمآن ؛ لذلك فهو يعتبر الميـاه مورداً مشتركاً، وأن ممارسـة السيادة الدائمـة على الموارد الطبيعية ينبغي ألا تحول دون التزام الدول بالمراعاة الواجبة للآثار الناجمة عن أنشطتها على اللدول الأخرى، ويرتبط مفهوم المورد الطبيعي المشترك مـع مفهومي التضامن والترابط اللذين يتجليين في فكرة شبكة المجـاري المائية الدولية، وينبغي ألا تتخذ السيادة كستار للأنانية في عالم تضطر فيه الدول إلى التعاون وفق أسس جديدة

بغية تعزيز التنمية فيها. (ن)

\section{ثالثًا : الاعتراف بهق هصر التاريخي في هياه النيل}

قد جاءت تعليمات وزير الخارجية البريطاني لممثله في مفاوضات اتفاق 9 ب 9 و بين مصر وبريطانيا لتعترف لمصر بحق تاريخي في مياه النيل فنصت على الآتي : " إن المبدأ المقبول هو أن مياه النيل التي تشمل في نفس الوقت مجرى النيل الأبيض

$$
\begin{aligned}
& \text { (1) انظر د/ محمد عبد العزيز مرزوق - مصر ودول حوض النيل ـ دراسة لقو اعد القانون الدولي التي }
\end{aligned}
$$

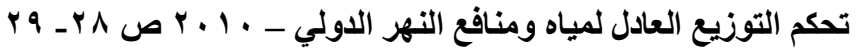

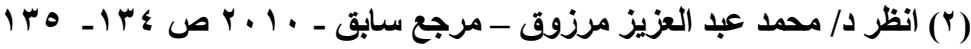


والنيـل الأزرق وكـللك جميع روافـها يجب أن تعامـل باعتبار هـا كـلاً واحداً مخصص للاستعمال بواسطة السكان الذين يعيشون على ضفاف النيل وفقاً لاحتياجـاتهم وقدرتهم على الاستفادة منها وطبقاً لهذا المبدأ فإنه من المعترف به أن مصر لها حق مكتسب في حفظ إمداداتها الحالية من المياه من أجل القطاعات الزراعية حالياً ، ولهذا نصيب عادل في جميع المصادر الإضافية التي قد تنتج عن تنفيذ مشروعات جديدة في المستقبل . وقد علق السيد " بير سميث " في كتابه الاستخدام الاقتصادي للأنهار الاولية على هذه المفاوضـات المصرية السودانية بقوله إن الموقف الذي اتخذته بريطانيا حيال مصر أثناء المفاوضات بثأن تقسيم ميـاه النيل هو نموذج طيب لنبذ فقـه السيادة الإقليمية المطلقة والحقوق المطلقة من قبل دولة كبرى ـ

وبعد اسـتقلال السودان عن مسصر، وخـلال المفاوضــات بين مصر والسودان

بصدد بناء السد العالي وتوزيع فائض المياه بين الدولتين؛ أعلنت حكومـة السودان " بأنها لا تجادل أبداً في أن مصر قد أثثتت وجود حق لها في نصيب من ماء النيل تستغله فعلاً لأغراض الزراعة ، وأن السودان يتمتع بنفس الحق ". وهنـا يعد اتفـق الدولتين حول توزيع الفائض من مياه النيل بعد إبرام اتفاقية / / / /9 /9 19 نموذجاً طيباً للتعاون بين الدول المطلة على نهر دولي واحد في كيفية ضبط وحفظ الميـاه وتوزيعها لفائدة الطرفين ، وهنـا لابـ أن تراعي أثيوبيـا مثل تلك القواعد والمبـادئ حين إبرامها لأيـة تغييرات على مجرى نهر النيل . (1) 


\section{رابعًا: هبادئ السلوك في الهفظ والاستخدام المتناسق للموارد الطبيعية المشتركة}

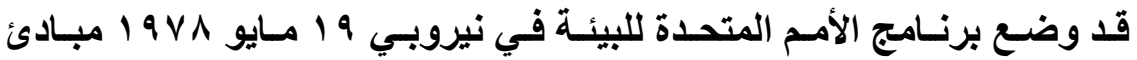
السلوك في الحفظ والاستخدام المتناست للموارد الطبيعية التي تشترك فيها دولتان أو

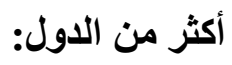

ا - المبدأ الأول: تتعاون الدول في مجال البيئة بالحفاظ والاستخدام المتناسق للموارد الطبيعية التي تشترك فيها دولتان أو أكثر من الدول. وذلك بالانتفاع المنصف للموارد الطبيعية المشتركة ، وتتعـاون الدول بغية التحكم ، ومنـع ، وخفض أو إزالة الآثار البيئية الضارة التي قد تتجم عن استخدام هذه الموارد ، ويتم ذلك على قدم المساواة مع مراعاة سيادة وحقوق ومصالح الدول المعنية. (1) r- المبدأ الثاني: ضرورة تعزيز التعاون من خـلال إبرام اتفاقـات ثثائية أو متعددة الأطراف فيما بينها من أجل تأمين لائحة محددة من سلوكهم، وتطبيق المبادئ الحالية حسب الاقتضاء على نحو ملزم قانونياً، أو تسعى للاخول في ترتيبات واتفاقات أخرى حسب الاقتضاء لهذا الغرض؛ وينبغي أن تنظر الدول في إنشاء الهياكل والمؤسسات من قبل اللجان والمشاكل البيئية المتعلقة بحماية واستخدام الموارد الطبيعية المشتركة. r- المبدأ الثالث: وفقا لميثاق الأمـ المتحدة ومبادئ القانون الدولي للاول الحق السيادي في استغلال مواردها وفقا لسياساتها البيئية الخاصة، تتحمل مسؤولية ضـــان أن الأنسشطة المـضطلع بهــا داخـل حـدود ســلطتها أو تعــ رقابتهـا 
لا تسبب ضررا لبيئة الدول الأخرى أو المنـاطق الواقعة خـارج حدود الولايـة

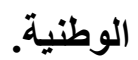

وقاعدة عدم الإضرار نجد لها أصل تاريخي على سبيل المثال في المادة (؟) من

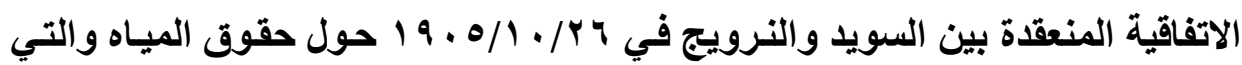
أشـارت إلى وجود مبادئ عامة التطبيق على الأنهار الدولية، ونصت المادة على " وفقا

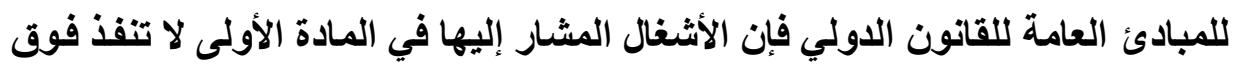
إقليم هذا الطرف أو ذاك بدون موافقة الطرف الآخر ، وإذا أضرت هذه الأشغال أو أثرت في المياه الواقعة في الدولية الأخرى ، أو أدت إلى تغيرات محسوسة أو جوهريـة في نوعية المياه فلا يمكن تنفيذها. (1)

§- المبدأ الرابع: تثقاسم الدول الموارد الطبيعية بثكل عادل ومنصف. (")

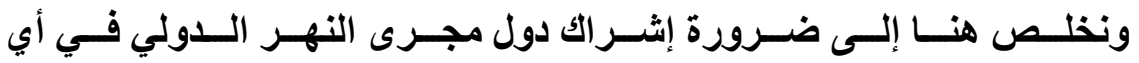

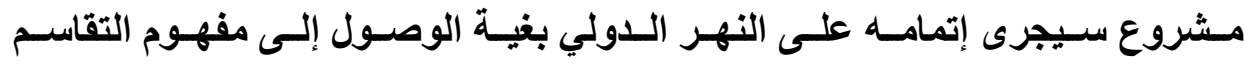

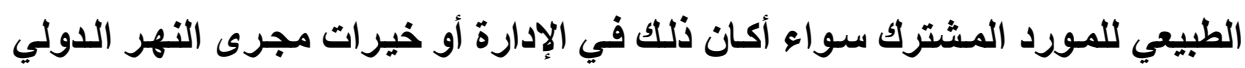
نفسه. 


\section{الامطب الثالث}

سد النهضة الأثيوبي

\section{أولاً : السند القانوني لأثيوبيا في بناء السد}

استتدت دولـه أثيوبيـا إلى فقهـ هـارمون سـالف الذكر ؛ وأعلنت دولـة أثيوبيـا

عزمها على بنـاء سد النهضة بأثيوبيا (') والذي تم تصميمه على النيل الأزرق قرب

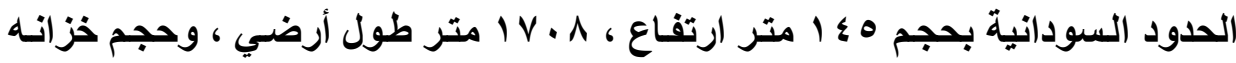

• 1 ا كمّ سيحجز • V مليـار متر مكعب مـن الميـاه ( أي أكبر من محتوى بحيرة

أثيوبيا الطبيعية الكبرى ) وسيدفع إلى إعادة توطين . . . . . شخص ، وتبلغ تكلفة بناءه ^, ^ مليار دولار ( أي ما يعادل ه ٪\% من الناتج المحلي الإجمالي في أثيوبيا في

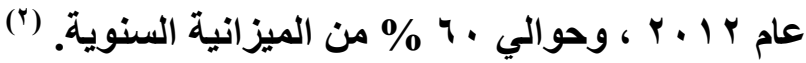

والأي ساعد في تفاقم مشكلة بناء السد هو عدم الثفافية في طرح فكرة البنـاء

سواء على المجتمع المحلي الأثيوبي أو على المجتمع الدولي؛ ومما قد يثير الصراع أن نهر النيل ثاني أكبر نهر في أفريقيا هو المفتاح لبقاء ، 17 مليون نسمة في إحدى

(1) WRR - international rivers organization - vol 27/ No 1 - March 2012 P 9 " Amid turmoil in Egypt, which has long held rights to most of waters of the Nile, the Ethiopian government announced it intends to build Africa's biggest Dam, the grand Ethiopian renaissance Dam, on the Nile."

$\left(^{2}\right)$ WRR - international rivers organization - September 2013 - vol 28No.3 - p 10 
عشرة بلاًا ، وهو أيضا عرضة لتغير المناخ، ومن المقرر بناء سدود أخرى في روافده العليا، والتـي سـوف تقلل من جريـان الميـاه ومـن ثم جفـاف دول المصب ، وتصاعد احتمالات الصراع على المياه ، مما يعطي دليلا على أن الحرب القادمة هي حرب المياه. (') إذ أن تصميم السد كبير جداً ؛ حيث يعد أكبر سد طاقة كهرومائية مقترح بأفريقيا، وهو معيب وفقا لتقارير وكالة أنباء "بلوم برج"، والتي استتدت فيها لمعلومـات وردت إليها من لجنة الخبراء الدولية المشكلة من أثيوبيا والدول المجاورة لها لاراسـة آثار مشروع سد النهضة على دول المصب؛ فلم يتم التصريح بمعلومات التقرير علناً. (ن)

(1) WRR - international rivers organization - vol 27/ No 2 - June 2012 - P 8-9" Human rights abuses : Dam development in Ethiopia is heavily politicized, and there is virtually no space for public debate or participation. Government repression has increased in the face of strong opposition to the Gibe III Dam, now being built on the Omo river. The controversial Dam is also fueling " land grabs ", which bring a new set of social concerns and abuses."

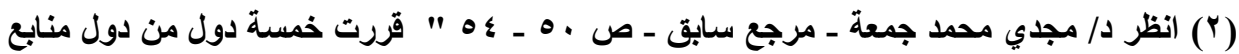

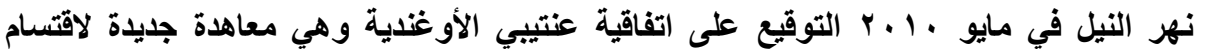

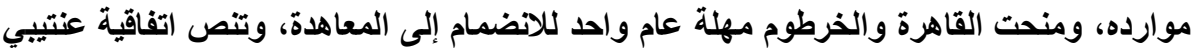

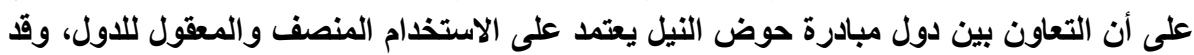

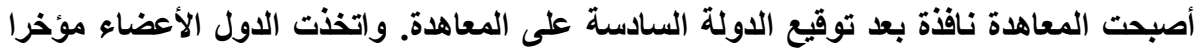

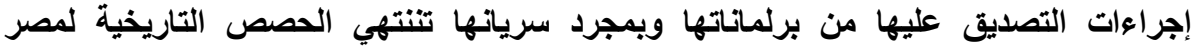

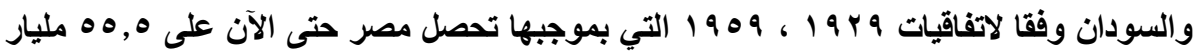

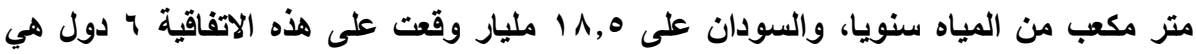

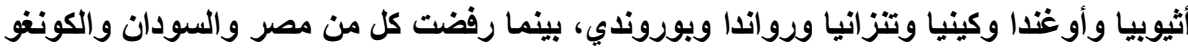

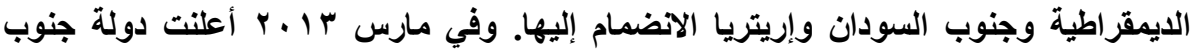

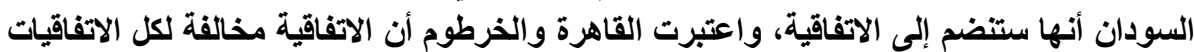

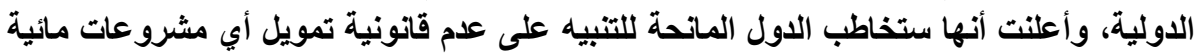

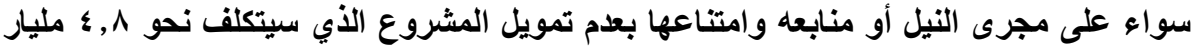
$=$ 


\section{ثانيًا : العيوب الفنية في بناء السد}

في مايو من عام ب ا ـ ج حولت أثيوبيا مجرى النيل الأزرق للثروع في بناء سد

النهضة ، أكبر سد حتى الآن لتوليد . . . . " ميجاوات " ، وهي الخطوة التي أثنارت

دولار أمريكي حسب رئيس الوزراء الأثيوبي الراحل (مليس زيناوي)، ولم تعر أثيوبيا احتجاجات

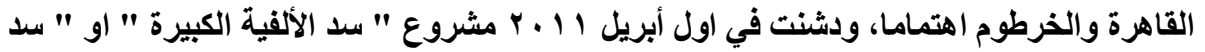

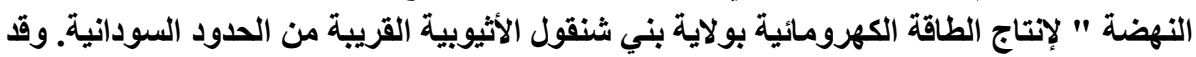

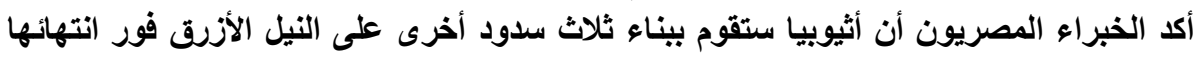

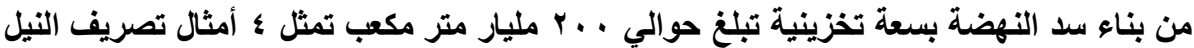

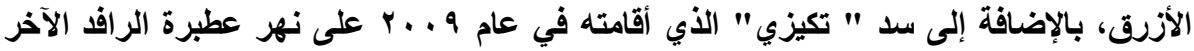

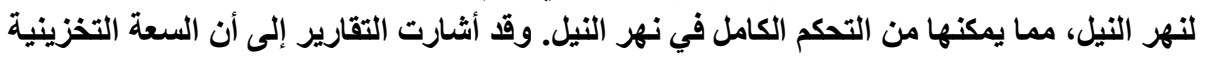

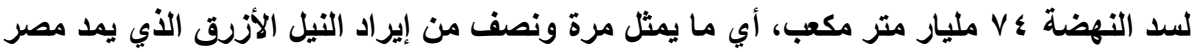

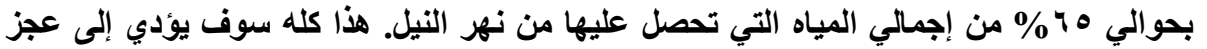

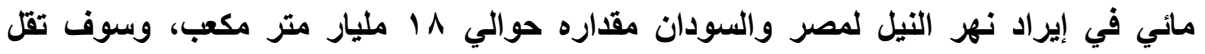

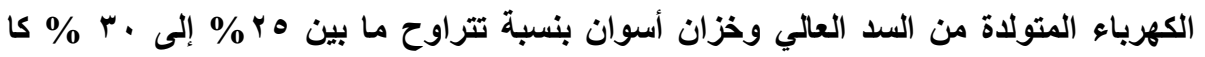

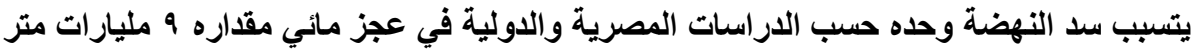

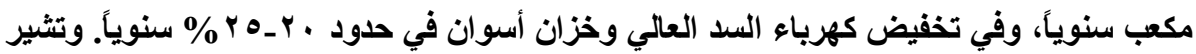

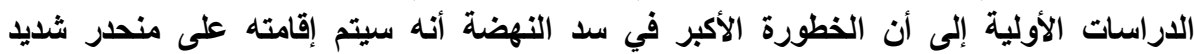

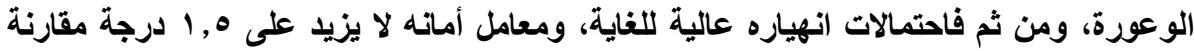

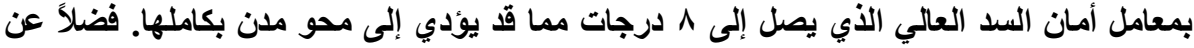

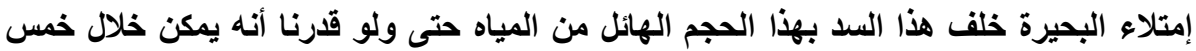

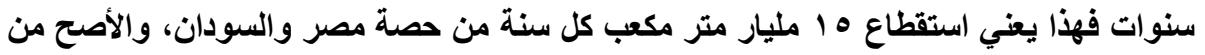

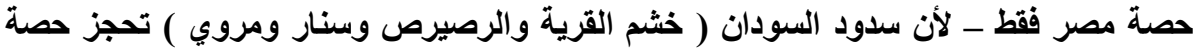

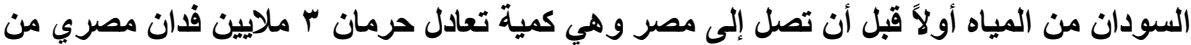

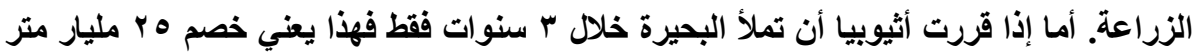

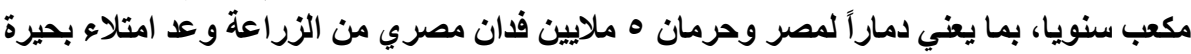

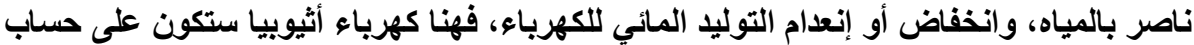

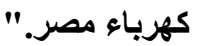


غضب مصر التي تخشى من تقلص إمدادات المياه على مدى سنوات عديدة سـوف يستغرقها ملء خزان ضخم، وبجانب هذه التوترات السياسية، فهنـاك قلق متزايد من عدم قدرة السد على إنتاج القدر المخطط له من الطاقة في تصميمه النظري ؛ حيث أن هناك عدد من المهندسين شكك في تصميم السد، وهذا مـا أوضحه " أسفاو بيين " أستاذ الهندسة الميكانيكية ومدير مركز الطاقة المتجددة وكفاءة استخدام الطاقة بجامعة ولاية " سان دييغو " الأمريكية ، حيث أوضح في مقابلة مع مجلة الأنهار الدولية حول بناء سد النهضة والعواقب التي ستتتج عنه كسد كبير الحجم ؛ فردد قائلاً الحوار التـالي " بناء سد كبير الحجم مثل سد النهضة ، يعني أن أكثر من نصف التوربينـات نـادراً مـا سيتم استخدامها ، فارتفاع السد ، ومعدل التدفق الطبيعي هما العاملان اللذان يحددان إنتاج الطاقة المحتملة، فالسد ارتفاعه هـ 1 متر ، ومعدل انتاجه . ... ب " ميجاوات " ، وليس هناك شك في أن نظام السد قد تم تصميمه لمعدل تدفق عال ، ولكن هذا التدفق العالي يحدث فقط خلال شهرين إلى ثلاثة شهور في موسم الأمطار، والمخطط هو سبعة عشر توربيناً ، وهذا العدد يتجاوز ما يمكن أن ينتج نظرياً، نظراً لارتفاع السد ، ومعدل تدفق ميـاه النهر، فاستهداف معدل مـا فوق المتوسط أو العـالي أمراً غير ذي مغذى اقتصادياً.

وجاء ذلك على إثر استخدام المهندسين لحساب مفـاده " عامل حمولـة المحطة " لوصف نسبة الإنتاج الفعلي لطاقة المحطة على مدى فترة من الزمن، أو إنتاجها المحتمل إذا كان من المكن أن تعمل بكامل طاقتها لأجل غير مسمى. وفي حالة سد

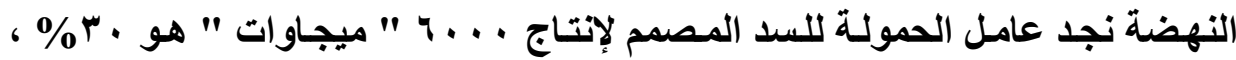

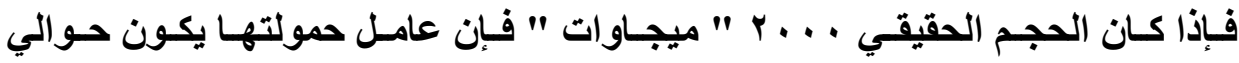
•9\%، ولما كان حجم السد مصمم لمعدل تدفق النهر متوسط ؛ فهو سيستمر بضعة 
أشـهر فقط ، ومعدل تدفق النيل الأزرق تعت . . . . متر مكعب / الثانية ، حتى ولو تجاوز . ه 7 / الثانية مرة واحدة مع ارتفاع ه ؛ ا متر للسد، فمعدل التدفق هذا هو الذي ينتج حوالي . . . . ميجاوات " ـ نجد أن متوسط معدل النيل الأزرق سيكون أقل بكثيز ، كذلك ونظراً لارتفاع السد ومعدل التدفق لا توجد وسيلة للسد في إنتاج . . . . . " ميجاوات " لأكثر من ثلاثة شهور في السنة، حتى ولو كان الخزان الخـاص بالسد قد خزن الفارق بين معدل التدفق الطبيعي ومعدل التدفق المخطط لـه، والسيناريو الوحيد الذي بموجبه إنتاج الطاقة سيكون متسقا سنوياً ؛ هو إذا تم تصميمه لتوليد الطاقة الكهرومائية لتدفق متوسط ، على سبيل المثال 70 ؛ 1 متر مكعب/الثانية، وهذا سبوفر فقط . . 1 Y " ميجاوات ". (') كل هذه الأمور الفنية توحي بفشل كبير في بناء مثل هذا السد فضلا عن ضعف قدرة هذا السد بهذا التصميم على حجز أكبر قدر من المياه خلفه، وما ينتج عن ذلك من جفاف وقحط ستتأثر به دول المجرى الأوسط للنهر ودول المصب نتيجة احتجاز المياه لملئ خزان كبير بهذا الحجم.

\section{ثالثًا : أثر عدم تناسب هبم السد هع همدل تدفق الملاء}

مسن آثـار عدم تناسـب حجم السد مـع معدل تـدفق المساء وعدم تناسـب عدد التوربينات المطلوبة مع الطاقة المتوقعة والمخطط لها؛ توقف عمل التوربينـات ؛ فمن المتوقع توقف عمل · ا توربينات أو أكثر لمدة تسعة أشهر من السنة ، فالحجم يتطلب سبع توربينات لتوليا ، ه ب " ميجاوات " لكل منهما، وحتى إذا أضفنـا توربينـا إضـافيا واحداً ، لفترة توقف الصيانة، فهرف التصميم المناسب لا يتجـاوز ، . ب " " ميجـاوات " ؛ وهذا يضمن وجود الكهرباء على مدار السنة في مستوى ثابت تقريباً ، وهذا الأمر

(1) WRR - international rivers organization - ibid - p 10 
يتطلب أيضاً فترة أقصر لمـلع الخزان الأول ـوالسعر الإجمـالي . . دولار/ للكيلو وات ، وقد حصلنا على هذا المعدل بقسمة V, ؛ بليون دولار على . . . 7 ميجا وات، وهذا هو المنهج المتبع في صناعة الطاقة ، حيث يؤدي بدوره إلى ب r بليون دولار ، وهو أقل بكثير من V, ؛ بليون دولار المقرر د ـ .. . . ميجا وات. (') وهذا يعني من الناحية الإنسانية ووفقا للبنك الدولي أن استخدام الأثيوبيين في المتوسط سيكون . . ب . كيلو وات / للساعة من الكهرباء للفرد الواحد في السنة. ونصيب الفرد بالمقارنة أقل من استفادته لأنـه يقل مـع النمو السكاني ، والمقارنـة الأفضل هـي وحدة الكيلو وات/ الساعة المستخدمة لكل أسرة سنوياً ، وهي عبارة عن . ه كيلو وات / سـاعة لجنوب الصحراء الكبرى بأفريقيا.

والغرض هنا من المقارنـة هي أن متوسط حوالي . ... با كيلو وات للساعة/ السنة ، وتستخدم الأسر الأمريكية متوسط . . . 1 ا كيلو وات للساعة / السنة، بمـا في ذلك الغاز الطبيعي والكهرباء. ولو افترضنا ـ . ـ كيلو وات للساعة/ السنة لكل أسرة، و . . . " ميجاوات " من " القوة المفقودة " يمكن أن تكون قد غطت أكثر من V مليون أسرة ( و لا يتضمن ذلك تكلفة خطوط نقل الطاقة ) ؛ وإذا أخذنا متوسط الأسر في جنوب أفريقيا ؛ سنجدها . . . ه كيلو وات للساعة / السنة ، وذلك قد يؤثر على تغطية سبعة ملايين أسرة.

لذا نحن نرى أن قضية بناء السد ودفاع أثيوبيا عنها بكل هذه الأخطاء الفنية أمرُ سياسـيُ في المقـام الأول ، وهذه السياسة الأثيوبية تقـع وتكبح النقد الهندسي المشروع من الناحية الفنيـة، والمناقشات البيئية ، وهنـا اقترح " أسفاو بيين " على (') WRR - ibid-p 10 
الجهات المعنية في أثيوبيا أن تلتزم الثفافية ، وإعادة النظر في عدد التوربينـات التي سيتم تثبيتها ، وتغيير حجم إنتاج الطاقة الكهرومائية من خلال تقليل عدد التوربينات ، حيث أنه قام بزيارة قبل عدة أسابيع من إجراء المقابلة مع المجلة لمحطة الطاقة المائية بالقرب من " لاسيرينا " تثيلي ، والذي توقف بسبب انخفاض منسوب المياه؛ ويرى أن سد النهضة سيواجه نفس المصير ما لم يتم تصحيح الحجم الخـاص بالسد والتزام

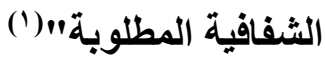

\section{رابهًا : هوقف دول المبب هن بناء سد النهضة الأثيوبي}

قد أعربـت مصر والسودان عن قلقها إزاء التغييرات على إمـداداتهم بالميـاه

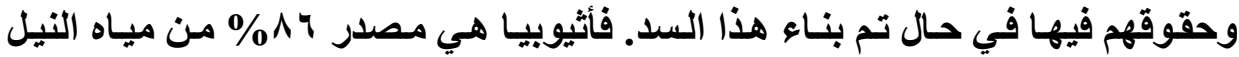
تخطط لبناء خزان كبير من الممكن أن يحتجز وراءه ما يتدفق بـه نهر النيل سنوياً من المياه(ץ) ، ولقد قدرت الدراسة الهيدرولوجية الأولية بأن مصر سوف تعاني انخفاضًاً بنسبة \\% في توليد الطاقة من سد أسوان العالي إذا امتلأ خزان سد النهضة الأثيوبي أثناء متوسط أو علو سنوات هطول الأمطار. ومع ذلك تكهن التقرير بـأن المشروع من شأنه أن يؤثر بشكل كبير على إمدادات المياه لمصر وتتسبب في فقدان توليد الطاقة في

(')WRR - ibid - p 10

$\left.{ }^{2}\right)$ Haggai - Erlich the cross and the river Ethiopia, Egypt and the Nile 2002 - Lyme Rienner publishers. - p 1-4" at the heart of the matter is the fact that 86 percent of the water irrigating Egypt comes from Ethiopia and Ethiopia itself intends to use a part of it. The waters of Ethiopia flow down the Nile tributaries of the Atbara river( the takkaze in Ethiopia ) and the sobat ( the Ethiopian baro-akobo) but mainly through the blue Nile, or the abbai " the big river and the father of rivers" for the Ethiopians. 
السد العالي بأسوان لفترات طويلة إذا امتلأ الخزان خلال سنوات الجفـاف ؛ وهنـا حثت اللجنة على إجراء مزيداً من الدراسات الثاملة ، فالتحاليل والدراسات بشأن المشروع أساسية جداً ، ولم ترق بعد إلى المستوى المطلوب والذي يتوافق مـع أهمية المشروع

وتأثيره على المتغيرات الإقليمية. (1)

وق بلأت التجاوزات الأثيوبية على مجرى نهر النيل منذ عام 901 بغرض فرض السيطرة على منـابع نهر النيل والاستحواذ على مياهـه وأكثر من ه^٪\% من

جملتها تأتي من الهضبة الاثيوبية . (r)

وفي تقرير للبنك الدولي صادر في عام • 1 ـ ج حول البنية التحتية الأفريقية ذكر

فيه : " حان الوقت للتحول " ، فقطاع الطاقة في أفريقيا يتطلب استثمارات سنوية تبلغ إ مليار دولار ؛ أي أكثر مما يحصل حالياً ، ولكن بنـاء السدود المائية الضخمة أقل بكثير مما تتطلبه إضاعة أفريقيا ـ ولماذا ، ذلك لسببين أكدوا على أن معدلات الكهربـاء في أفريقيا جـاءت متأخرة خلف كل منطقة أخرى في العـالم والأكثر من ذلك وبشكل صارخ يوجد في أفريقيا بجنوب الصحراء الكبرى حيث لا يوجد سوى ^٪\% من سكان الريف، و Y \% من مجموع سكانها لايهم القدرة على الحصول على الكهرباء.

- السبب الأول: معظم هؤلاء يعيشون دون كهرباء وبعيداً عن الاتصال بالإمدادات

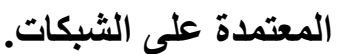

(1) Susanne Wong - WRR - international rivers organization - Vol.28/no.4 - December - 2013 - p13 " news briefs".

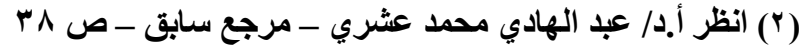


- السبب الثاني : بالنسبة إلى أولئك القريبين من الثبكة نجد أن شبكات التوزيع

في أفريقيا تعاني من نقص التمويل بشكل غير متناسب. (')

\section{خاهسًاً : البنك الدولي ودوره في بناء السدود:}

يبقى البنـك الدولي اللاعب الأكثر تـأثيراً في مسار تنميـة الطاقة في أفريقيا ؛

فرغم محدوديته إلا أن قروضه لبناء السدود تثزايد في السنوات الأخيرة، فوثائق البنك الاولي بما في ذلك خطة عمل أفريقيا ، واستراتيجية قطاع الطاقة (؟) ، واستراتيجية قطـاع الميـاه تساعد على تبريـر بنـاء السدود الكبيرة على نطـاق واسـع في أفريقيـا. ويواصل البنك الدولي التأثير على سياسات الدول الأفريقية وإقراض المال لبناء السدود فضلاً عن البنية التحتية المرتبطة بها، إنه أحد الأدوار المؤثرة للبنـك الدولي هو تنفيذ البنية التحتية الأفريقية للبلد محل الإقراض ( مشروع أيكد ) وهو مشروع يهدف إلى

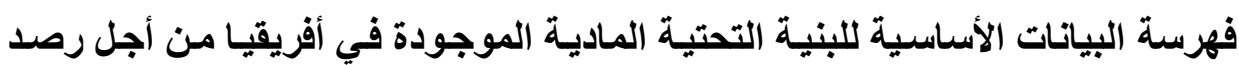
نتائج استثمارات الماتحين في المستقبل؛ وتضم اللجنة التوجيهية ( أيكد) كل من الاتحاد الأفريقي، والجماعـات الاقتصادية الإقليميـة في أفريقيـا، والبنـك الأفريقـي للتنميـة ، والجهات المانحة للبنية التحتية الرئيسية. وجاء تقرير (أيكد) في ^ . . ب بأن مستقبل الطاقة في أفريقيا يكمن في توليد الطاقة الكهربائية.

(1) Terri Hathaway - WRR - international rivers organization - December - 2010 - p 4/10 " what is driving dams in Africa?".

${ }^{2}$ ) Seleshi bekele Awulachew and others - The Nile river basin - water agriculture - governance and livelihoods - 2012 - p 18 - " Power electricity on the Nile - past and future "

$\left({ }^{3}\right)$ Terri Hathaway -Ibid - p 4/10 


\section{سادسًا : فشل السدود الكبيرة}

يعرف فشل السدود الكبيرة مـن قبـل اللجنـة الاوليـة للسدود الكبيرة باسـم " الانهيار أو الحركة في جزء من السد أو أساساته ، بحيث لا يمكن للسد الاحتفاظ بالمياه الموجودة خلقه "، وبشكل عام ينتج عن ذلك فشل في الاحتفـاظ عن كميات كبيرة من الماء مما يشكل مخاطر جدية للشعب والممتلكات في دول المصب، وكانت التتائج التي توصلت إليها اللجنة الدولية للسدود الكبيرة في تقريرها هي:-

ا ـ معدل الفشل في السدود الكبيرة قد انخفض بشكل كبير في العقود الأربعـة

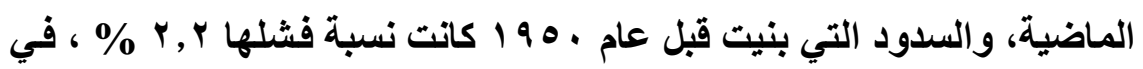

حين أن نسبة الفشل في السدود التي بنيت منذ عام 1901 أقل من ه, •٪\% r ـ نسبة السدود الفاشلة تختلف قليلاً مع ارتفاع السدود وحتى معظم حالات الفشل تنطوي على السدود الصغيرة. rـ تنطوي معظم حالات الفشل على سدود بنيت حديثاً ، حوالي • V \% من حالات الفشل تحدث في العشر سنوات الأولى من عمر السد، وبشكل متناسب أكثر خلال السنة الأولى بعد بلءء العمل والتشغيل.

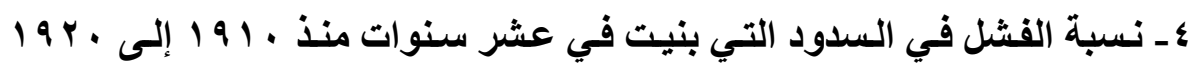

$$
\text { كاتت كبيرة. }
$$

هـ تعد مشـاكل الأسـاسـات هي أكثر أسباب الفشل في خرسـانة السدود، فضلاً عن التآكل الداخلي والتقطع والتهتك في جدار السد وذلك بنسبة اץ \% من السدود الفاشلة. 
צـ السبب الأكثر شيوعاً في الفشل هو امتلاء السدود بالصخور والرواسب والذي

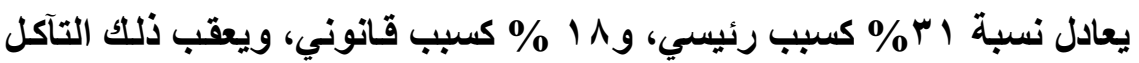

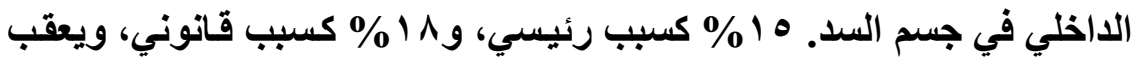
ذلتك التآكل الداخلي في جسم السد، وه |\% كسبب رئيسي، وس | \% كسبب ثانوي، وتآكل أساسات السد بنسبة ب | \% كسبب رئيسي، وه\% كسبب ثنانوي. Vـ مـع السدود الحجريـة، كـان السبب الأكثر شيوعا والذي يحتل المرتبـة الأولى

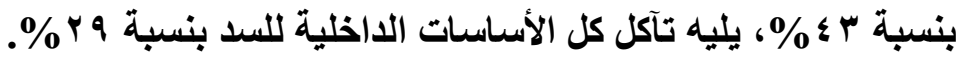
1- حيثما كاتت هناك أسباب أخرى للفشل، كان السبب الأكثر شيوعاً هو عدم كفاية القدرة على تصريف الفـائض عن التخزين، وكسان ذلك بنسبة r r \% كسبب رئيسي، و · \% \% كبب ثانوي. وـ كان العمل في مرحلة مـا بعد الفشل المبلـغ عنه في معظم الأحيان وفق النسب

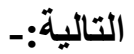
1 التخلي عن المخطط الأصلي للسد الفاشل بنسبة ؟ץ\%٪.

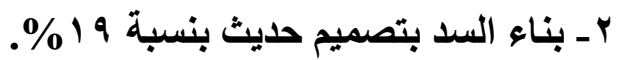

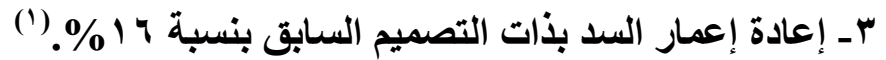
والملاحظ أنه وفقاً للنسب السابقة أن السدود الكبيرة لها قدر من الفشل رغم دقة الالتزام بالتفاصيل الهندسية والقنية في بناء السدود، وهذا مالم تراعيه أثيوبيا في

(1) Dams and development - Op.cit - p 63 
بنـاء ســـ النهـضة وفقـا للـكتور " أسـفاو بيــن " في مسا سـلف ذكره في معرض الحـيث عن عيوب بنـاء سـد النهضة الأثيوبي، ومـن ثم سـتكون نسبة الفشل فيـه كبيرة.

\section{سابهاً : التزبيب في السدود الكبيرة}

العديد من الخزانـات تخضع إلى حد مـا لتدفق الرواسب والترسيبات، وتشير

التقديرات إلى أنه بنسبة ه, · إلى \\% من الخزانات تفقد بسبب حجم الترسيب داخل

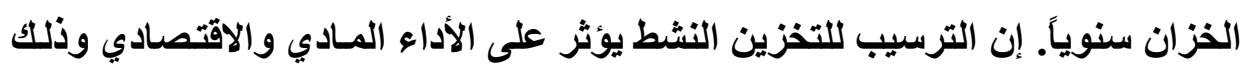
فقط عندما يكون تصميم الخزان أكثر أو أقل استخداما ممـا ينبغي وفي نهايـة المطاف؛ فإن الترسيب سيؤثر على حياة المشروع بسبب زيـادة الطـي اللزج في أسفل الخزان مما يؤدي إلى انسداد مصارف ومداخل المياه التي يعتمد عليها السد. ففي سد تـاربيلا الأي يواجه مشكلة في الترسيب نجد أن الخزان فقد ^ \1\% من عمره الافتراضسي بعد ه r عامَاً، على الرغم من أن التوقعات كاتت تخالف ذلك أو بالأصح كاتت غير صـادقة؛ وهنا فقدان القدرة على التخزين يقلل من القدرة على الري، بالإضـافة إلى أن تراكم الرواسـب بـالقرب مـن السد يهـد حبـاة السد قبـل المـدة المحددة لإنتهائـه أو لفقدانـهـ

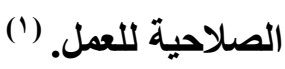

\section{ثاهنًا : الصين وبناء السدود}

بناة السدود الجدد في أفريقيا اليوم هم الصينيون ففي مـا بين عامين I +. . ب و V . . V التزمت الصين بـأكثر من ب مليـارات دولار لمشـاريع الطاقة المائيـة الأفريقيـة

(1) Dams and development - Ibid - p 65-66

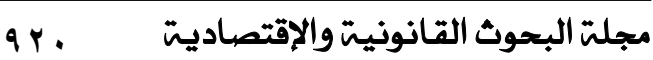


ومنذ ذلك الحين وسعت الصين بثكل كبير اهتمامها ، وعملت على تمويل البنية التحتية الأفريقية الجديدة، وشمل ذلك السدود ، وقد تميز منتدى التعاون بين الصين وأفريقيا (فوكاتك) بملامح العلاقة الرسمية بين الصين وأفريقيا في العقد الماضي.

ففي قمـة منتدى التعاون الصيني الأفريقي عـام 9 . . . تعهدت الصين بعشرة

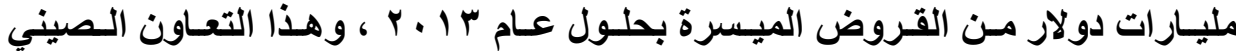
الأفريقي لم يكن محل ضرر للصين ؛ فقد استفادوا منه بطريقتين:-

1 ـ أنه يساعد الشركات الصينية للوصول إلى الموارد الطبيعية في أفريقيا والذي يدعم بشكل أساسي الصناعات الصينية. r ـ إغراق السوق المحلية الصينية بعدد كبيز جداً من الشركات الهندسية والعاملة في البناء تبحث عن فرصـة للعدل، ويوفر السوق الأفريقي نطاقَ واسعاً لهذه

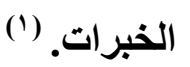

تاسعًا : عدم فعالية اتفاقية المجاري المائية غير الملاحيسة 1994 لمعالجـة الوضـع

\section{في نهر النيل}

سعت الأمم المتحدة إلى وضع قواعد عامـة تنظم استخدام كافة الأنهار الدولية

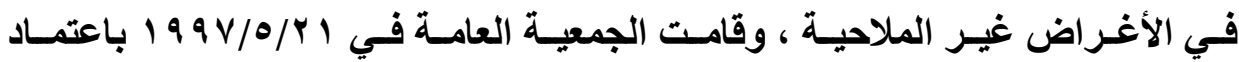
القـرار الخـاص باتفاقيـة " قـانون اسـتخدام المجـاري المائيـة الدوليـة في الأغـراض غير الملاحية "؛ إلا أن الاتفاقية بوضعها الحالي لا تقدم أي حماية لمياه نهر النيل نظراً

(1) Terri Hathaway -Ibid - p 4/10 


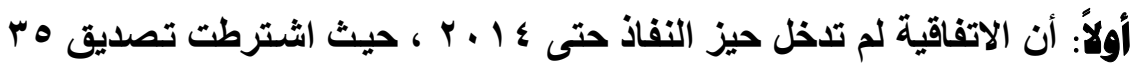
دولة لاخول الاتفاقية حيز التتفيذ بينما لم تصدق حتى الآن سوى ^ دول.

ثانيــا: الطابع الإطاري للاتفاقية، فـلا يمكن للاتفاقيـة أن تكون قابلـة للتطبيق المباشر لنهر النيل، وتأخذ في اعتبارها القواعد والمبادئ العامـة التي أقرتها الاتفاقية الإطارية خاصة الجغرافية والمناخية والتاريخية والهيدرولوجية لنهر النيل، والاتفاقيات الثنائية والمتعددة الأطراف التي سبق توقيعها بين بعض الاول. ثالث: موقف دول حوض النيل من الاتفاقية ، فبالرغم من نسبة القبول العام

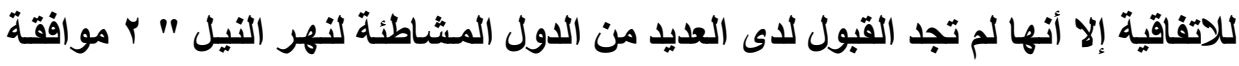

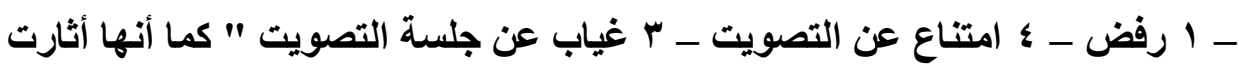
في بعض بنودها خلافا ما بين دول المنبع ودول المصب. (1)

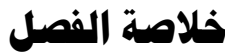

يلاحظ مما سبق أن دول نهر النيل لم تتفق بالإجماع على بنـاء سد النهضة ،

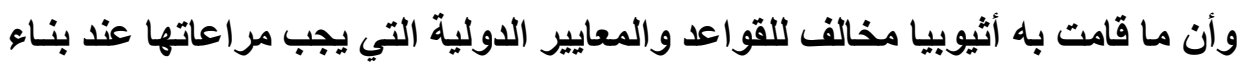
السدود الدولية خاصة كبيرة الحجم التي تحتاج كمية كبيرة من المياه في خزانات السد

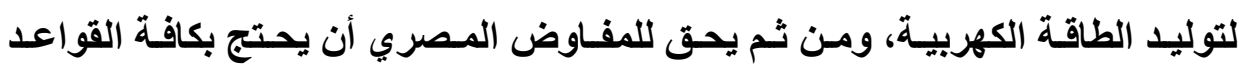
الاولية في أي محفل دولي للحفاظ على حقوق مصر في مياه نهر النيل استتادا على مخالفة أثيوبيا لقو اعد بناء السدود على الأتهار الدولية. 


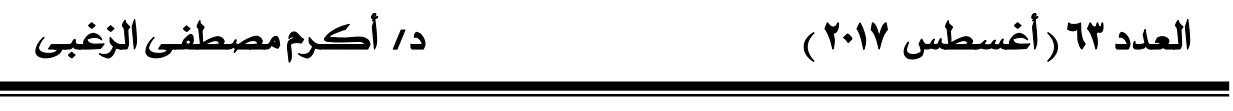

الفصل الثاني

الأولويات الاستراتيجية في بناء السدود

\author{
المبحث الأول \\ دور معهد القانون الدولي وقواعد هلسنكي \\ في حماية حقوق الدول النهرية
}

\author{
المطاب الأول \\ دور هعهد القانون الدولي في حماية حقوق الدول النهرية
}

أولاً : التنظيم الدولي لاستعمال الجاري المائية الدولية

قد أصدر معهد القانون الدولي في دورته المنعقدة بمدريد 1911 اقراراً حول التنظيم الدولي لاستعمال المجاري المائية؛ احتوى على القواعد الآتية:

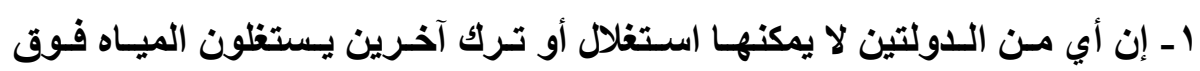

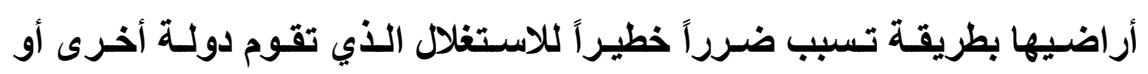

أثخاص أو شركات.

مجلت البحوث القانونيت والإقتصاديت 
r ـ عندما يشث المجرى المـائي مجراه عبر أقاليم دولتين أو أكثر بالتتابع فِإن كل تغيير ضار بالمياه وكل صب لمواد ضارة من مخلفات المصانع وغيرها هو أمر محظور. بـ الاولة الواقعة عند المصب لا يمكنها بنـاء سدود فوق إقليم في دولة مـا يترتب

عليها إغراق أرض دولة المنبع. (1)

ورغم أن الدولة في ممارستها لسيادتها على الجزء من النهر الذي يمر بأرضها ؛ فهي تسنطيع تنظيم الانتفاع بالنهر كما تثاء في بناء السدود والقناطر. إلا أنها تلتزم بالواجب الذي يفرضـه القانون الدولي بالامتنـاع عن تعريض مصالح الدول النهريـة الأخرى للخطر أو إضاعة فرص الدول الأخرى في الانتفاع بالمياه لخدمة احتياجاتها (') الوطنية الخاصة. ويدعم مبدأ عدم الاستعمال الضار ما أيده المبدأ رقم اب من إعلان مؤتمر الأمم

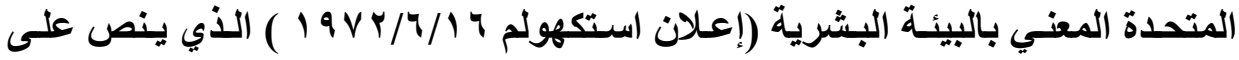
الآتي :" للاول وفقاً لميثاق الأمم المتحدة ولمبادئ القانون الدولي، الحق السيادي في استغلال مواردها الخاصة طبقاً لسيادتها البيئية الخاصة وتتحمل المسئولية عن ضمان ألا تسبب الأنشطة المضطلع بها داخل نطاق ولايتها أو تحت سيطرتها ضرراً لبيــة الدول الأخرى، ولبيئة المناطق الواقعة خارج حدود الولاية الوطنية. (ז)

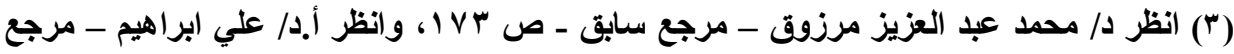


وفي إعـلان " منتفـيو " حـل اسـتعمال الأنهـار الدوليـة لأغراض الصناعة

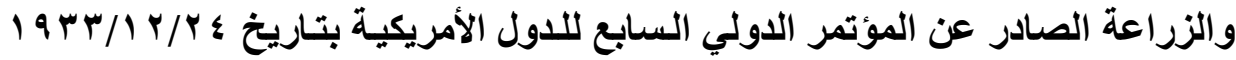
ينص على " الاول لها حق مقصور عليها في استغلال مياه الأنهار الدولية لأغراض الصناعة والزراعة في الجزء من النهر الذي يخضع لسيادتها، ومـع ذلكك فإن ممارسـة هذا الحق مقيدة بضرورة عدم الإضرار بـالحق المتسـاو المعترف بـه للاول المجاورة حيال الجزء من النهر الأي يخضع لسيادتها. (') ثانياً : مسئولية الدوالة مسئولية هطاقة يرى البعض أنه تعد مسئولية الدولة منشأ الضرر مسئولية مطلقة عن أي ضرر ملموس، فتعفى الدولة من المسئولية عن الضرر إذا كاتت قد اتخذت جميع التدابير اللازمـة والمناسبة لعدم حدوث الضرر، فـالالتزام الواقع على الدولـة النهريـة هنـا هو التزام بيذل عنايـة وكل مـا هو مطلوب لا يزيــ عن أن الدولـة النهريـة التي نجم عن اسـتعمالها ضـرر ملمـوس ألا يثبت فـي حقهـا أنهـا أخلـت بواجب العنايـة المطلوبـة والحرص على مصالح وحقوق الآخرين سواء أكان ذلك راجعاً إلى سلوك عمدي أم إلى إهمال من جانبها، أو لم تمنع شخصاً ثالثًا فوق أرضها من إحداث مثل هذا الضرر، أو تقاعست عن القيام بالإجراءات اللازمة من أجل وقف الضرر أو التخفيف من آثاره على الدول النهرية الأخرى. وفي مثل هذه الحالة تتحمل الدولة المسئولية الدولية لأنها لم تتخـذ الإجراءات المناسبة أو لـم تعمل على تطبيق القـانون الذي يمنـع النشاط غير المشروع، وهنا يصبح الإهمـال فعلاً منسوباً إليها لتقصيرها في بـذل العناية الواجبة. ولكن لا شُئل الدولة عن الأضرار التي ترتبها الأوضاع الطبيعية، كما أنها ليست ملزمة 
بتعديل هذه الأوضـاع. ولقيـام المسئولية الدولية يجب أن يكون هنـاك ضـرر وعلاقة سبيية بين هذا الضرر تصرف الدولة أو امتناعها عن التصرف.وفي قضية "فورتمبرج " بروسيا ضد بادن عام I I IV ذكرت المحكمة الاستورية العليا في ألمانيا أن قاعدة عدم جواز استخدام الدولة لأراضيها على نحو يحول دون تدفق مياه أحد الأنهار الدولية إلى أراضي أحد جيرانها يتجاوز مجرد واجب عدم الإضرار بمصالح الأعضاء الآخرين في المجتمع الدولي. ثالثًا : إلزاهية التوزيع والاستفدام العادل والمنصف :

يـرى البعض أن التوزيـع العـادل والمنـف لميـاه المجـاري المائيـة هـي قاعدة قانونيـة ملزمـة، وهنـاك إجمـاع من الفقهـه الدولي على اعتبـار قاعدة الاستخدام العـادل لثبكات المياه الدولية من القواعد العرفية الدولية كنتيجة طبيعية لمبدأ اشتراك الدول المشاطئة في النهر الدولي كمورد طبيعي مشترك لا يقبل التجزئـة بطبيعته ، وهذه القاعدة هي القانون الذي يفصل في النزاعات الدولية عند تعارض استخدامات النهر بواسطة أكثر من دولة مشاطئة، وذلك في ضوء المعاهدات الدولية وإعلانـات الدول المعنية بتنظيم استعمال تلك الأنهار. (') ويعد الاستخدام المعقول هو الاستخدام الرشيد والفعال الذي يؤمن للأطراف مزايا جوهرية أساسية مـع تجنب الفقد غير المجدي من الميـاه، وعلى سبيل المثال/ تنص المادة r من ميثاق الحقوق والواجبات الاقتصادية للاول على أن تتعهد الدول بأن يتم استغلال الموارد الطبيعيـة المشتركة بالتعاون فيمـا بينها وبقصد كفالـة الاستغلال

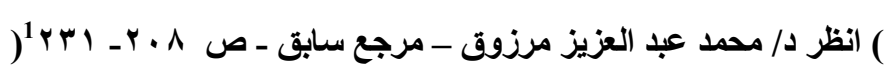


الأمثل لهـا في حين أن مـا ينطوي عليـه مفهوم الإنـصاف هـو الاقتسـام المتساوي والاعتراف بالمساواة في حق استخدام المياه للأغراض النافعة.

وقاعدة الاشتراك العادل والمعقول في مياه النهر هي قاعدة عرفيـة قامت لجنـة القانون الدولي بتقنينها ، وأخذت بها اتفاقية الأمم المتحدة للمجاري المائية في غير

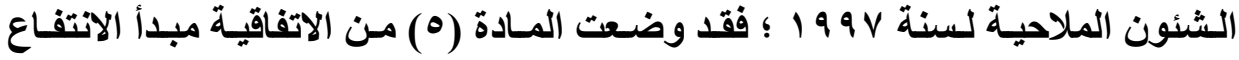
والمشاركة العادلين والمعقولين كحجر أسـاس للقانون ؛ حيث تنص الفقرة (1) منها على أن تنتفع دول المجرى المـائي كـلاً في إقليمهـا بـالمجرى المسائي بطريقـة عادلـة ومعقولة.

ويعني مبدأ الاستخدام العـادل والمعقول بـأن دول المجرى المسائي الدولي لهـا حقوق متعادلـة ومتر ابطـة في اسـتخدامات المجرى المـائي ومنافعـه، ولا يعنـي مبــأ المساواة في السيادة بين الدول أن كل دولة من دول الحوض المائي تأخذ نصيباً مساوياً بالتمام والكمال لنصيب غيرها من الدول الأخرى المعنية بالاستعمال والمزايـا المستمدة من المياه؛ فالتساوي ليس حسابياً ، وإنمـا يعني أن كل دولـة لها الحق في استعمال مجرى المياه والاستفادة منه على نحو عادل ومنصف حتى ولو كانت هناك دول أخرى تأخذ نصيباً أكبر منها في المياه. (1) رابعًا : ضوابط وهماييز الاستخدام العادل والمنصف

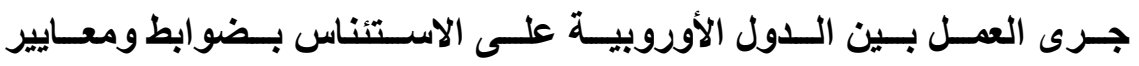
مختلفـة للتقسيم العـادل وفقـا لظروف كل نهر ومن يقطنون مـن الأهـالي على النهر،

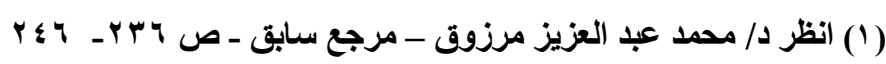


وتثير المادة (•) من قواعد هلسنكي إلى بعض العوامل التي يجب مراعاتها لتحقيق الاتتفاع العاقل بميـاه الأنهار الدولية فتنص على مـا يلي: " يتقرر النصيب المعقول والعادل في ضوء جميع العوامل ذات الصلة في كل حالة على حدة وهي على سبيل المثال لا الحصر:

أ- جغرافيـة الحسوض بمـا في ذلـك نطساق مسساحة الصرف في أراضسي كل دولـة حوضية بوجه خاص. ب- هيدرولوجية الحوض بما في ذلك على وجه الخصوص إسهام كل دولة من دول

$$
\text { الحوض في الماء. }
$$

$$
\text { ج- المناخ المؤثر على الحوض. }
$$

دـ الانتفاع السابق بمياه الحوض وكذلك الانتفاع الحالي بوجه خاص. هـ عدد السكان الذين يعتمدون على مياه الحوض في كل دولة من دول الحوض.

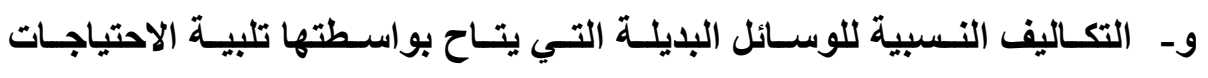
الاقتصادية والاجتماعية لكل دولة من دول الحوض.

$$
\text { ز- - ما يتوافر من موارد أخرى. }
$$

ح- كيفية تجنب الفقد الذي لا مبرر له في استخدام مياه الحوض. طــ الإمكانية العملية لتعويض دولة أو أكثر من الدول المثاركة في الحوض كوسيلة لتسوية المناز عات حول استخدام المياه. ي- مدى إمكانية تلبية حاجـات دولـة من دول الحوض دون التسبب في ضرر كبير لاولة مشتركة في نفس الحوض. ويتقرر شأن كل عامل من العوامل المذكورة في ضوء أهميته بالنسبة لأهمية غيره من العوامل ؛ ويجب عند تحديد ما هو النصيب المعقول والمنصف مراعاة كافة 
العوامـل المتـصلة بالموضـوع والتوصـل إلـى نتيجـة تقـوم على أسـاس تلـك العوامـل

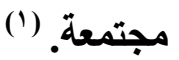

ومما سبق نلحظ أن كافة العوامل التي أوردها معهز القانون الاولي للحفاظ على حقوق الدول النهرية هي قواعد ملزمة نظراً لوجود عرف دولي جرت الممارسة الدولية على اتباعه لفترات طويلة توحي برسوخ القاعدة الاولية المتفرعة عن هذه الممارسـة وهـي ضـرورة التنظيم الـدولي لاسـتعمال المجـاري المائيـة الدوليـة ومسسئولية الدولـة مسسئولية مطلقـة عـن أي نسشاطات علـى مجـرى النهـر الـدولي وإلزاميــة التوزيـع والاسـتخدام العـادل والمنـف لميـاه مجرى النهر الـدولي ووجـوب الالتزام بـوابط ومعاييز الاستخدام العادل والمنصف.

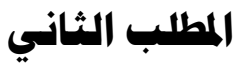

\section{دور معهد القانون الدولي}

\section{في إقرار هبدأ التوزيع العادل والمنصف}

قـ اعتبر معهد القـانون الـدولي أن التوزيـع العـادل والمنـصف وعـدم جـواز الإضرار بالآخرين هو المبدأ الذي يحكم علاقات الدول النهريـة ، فقي دورتـه المنعقدة بمدريد عام 1919 أصدر قرارا حول التظيم الدولي لاستعمال المجاري المائية احتوى على القواعد الآتية : - ملية

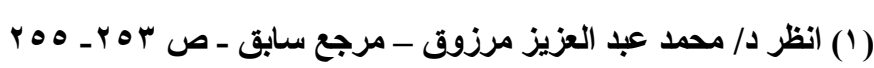


1 ـ عندما يشكل المجرى المائي حدوداً بين دولتين فأي منهما لا يمكنها بدون رضاء الأخرى ، وفي حالـة غياب سند قانوني خـاص ونافذ ، أن تحدث فيه أو تترك أشخاصاً أو شركات يحدثون فيه تغييرات ضارة بإقليم الاولة الأخرى. ومن ناحية أخرى فِإن أي من الدولتين لا يمكنها استغلال أو أن تترك آخرين يستغلون المياه فوق أرضها بطريقة تحدث ضرراً خطيراً للاستغلال الذي تقوم به دولة أخرى أو أشخاص أو شركات. r ـ عندما يثق المجرى المسائي مجراه عبر أقاليم دولتين أو أكثر بالتتابع فإن كل تغيير ضار بالمياه وكل صب لمواد ضارة من مخلفات المصانع وغيرها هو أمر محظور ؛ ولا يجب أن يترتب على أخذ أو سحب المياه من أجل توليد الطاقة الكهربائية أي تغيير خطير في كمية المياه أو نوعيتها ، ولا تغيير في مجرى الماء في دولة المصب ، وأن الدولة الواقعة عند المصب لا يمكنها بنـاء سدود فوق إقليمها يترتب عليها إغراق الأرض في دولة المنبع . قواعد هلسنكي حول استعمالات ميـاه الأنهار الدوليـة والصـادرة عن جمعيـة القانون الدولي في مؤتمرها المنعقد بهلسنكي عام 979 أس في الفصل الثاني من قواعد هلسنكي المتعلق " بالاستغلال العـادل لميـاه حوض الصرف الدولي " اشتملت على الأحكام التالية : تنص المـادة ؛ " كل دولـة من دول حوض الصرف الدولي لها فوق إقليمها حق في الاشتراك المعقول والعادل في المزايـا التي يوفرهـا استعمال ميـاه حوض الصرف الدولي " ـ وتنص المـادة ه " مـضمون تعبير " الاثتراك المعقول والعادل " المنصوص عليه في المادة الرابعة يتم تحديده في كل حالة خاصـة مـع الأخذ في الاعتبار لكل العوامل ذات الصلة ـ وهذه العوامل التي 
تؤخذ في الاعتبار عند توزيع المياه : ومنها كثرة عدد السكان أو قلتهم في كل دولـة ، وإمكانية وجود بدائل لزيادة إيراد النهر ، ومراعاة الحصة التاريخية التي تستغلها كل دولة قبل إجراء عملية التوزيع والتقسيم ، وغير ذلك من عوامل قد تساهم في ضبط معيار التوزيع العادل والمنصف لمياه النهر الدولي . (') ونخلص هنا إلى أن مـا توصل إليه معهد القانون الدولي من ضرورة احترام مبدأ الاقتسام العادل والمنصف لميـاه نهز النيل أضحى قاعدة قانونيـة ملزمسة لتواتر النص عليه في الاتفاقيات الثنائية والمتعددة بين الدول النهرية فضلاً عن كسبه لوصف العرف

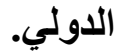

\section{الإملب الثالث}

\section{لجنة السدود الدولية والأولويات الاستراتيجية لبناء السدود}

\section{حددت لجنة السدود الدولية عدة أولويات استراتيجية لبناء السدود الكبيرة:}

أولاً : الأولوية الاستراتيجية الأولى: ” كسب القبول العام ". وهنا أوصت البنة بوضع مبادئ سياسية في المقام الأول: 1ـ الاعتراف بأن الحقوق الثابتة وتقييم المخاطر هي أساس لتحديد و إشراك أصحاب المصلحة الحقيقية في صنع القرار في مجال الطاقة وتنمية موارد المياه.

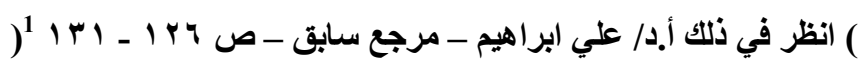




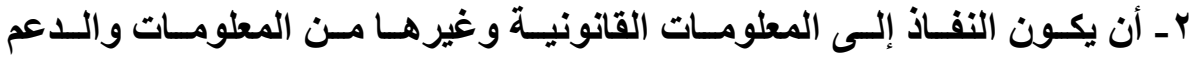
متاحسا لجميع أصحاب المصلحة ، لا سيما الشعوب الأصلية والقبلية والنساء وغيرهم من الفئات الضعيفة لتمكينهم من المشاركة الواعية في عمليـات صنع

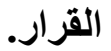

rا إثبــات وتحقيـق القبـول العـام، ويتحقـق ذلــك مـن خــلال القـرارت الرئيسـية

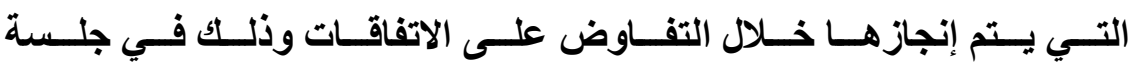
مفتوحة ووفق عمليـة شـافة، وبحسن نيـة، وبعلـم ومشـاركة جميع أصـاب المصلحة. عـ القرارت بشأن المشاريع التي تؤثُر على الشعوب الأصلية والقبليـة لا بـ مـن الحصول على موافقـة مستنيرة وحرة ومسبقة مسن خـلال الأجهزة الرسـية المفوضة والأطراف غير الرسميين. (') وإذا قمنا بتطبيق هذه الأولوية على ما تفعله أثيوبيا الآن في بناءها لسد النهضة نجد أن أثيوبيا لم تكسب القبول العام من سكان المنطقة المحيطة بنهر النيل. ثانيًاً : الأولوية الاستراتيجية الثانية: " التقييم الشاهل للخيارات ". يقصد بتطبيق هذه الأولوية

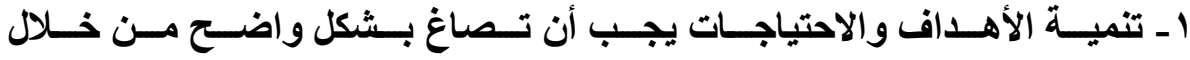

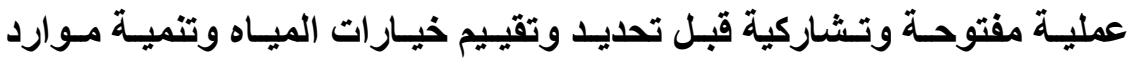
الطاقة.

(1) Dams and development - Op.cit - p 215 
r- لابد أن تأخذ مناهج التخطيط في حسبانها مجموعة متكاملة من الأهداف الإنمائية

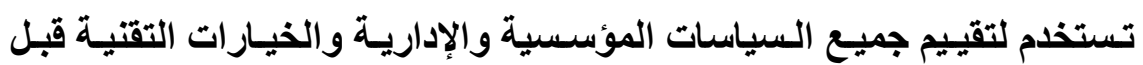

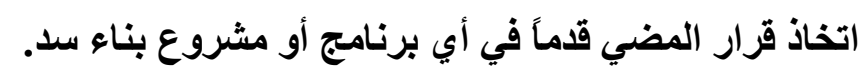

r- يتم إعطاء الجوانب الاجتماعية والبيئية نفس الأهمية التي تعطي للعو امل المالية

$$
\text { و الاقتصادية والفنية في تقييم الخيارات. }
$$

ع - زيادة الفعالية واستدامة المياه القائمة والري وأنظمة الطاقة تعطي الأولوية في

$$
\text { عملية تقييم الخيارات. }
$$

هـ إذا تم اختيار سداً ما من خلال عملية تقييم خيارات شـاملة، فهنا تطبق المبادئ الاجتماعية والبيئية في استعراض وتداريد الخيارات في جميع أنحاء التخطيط

التفصيلي و التصميم والبناء ومر احل عملية التقييم. (')

وإذا قمنا أيضا بتطبيق هذه الأولوية على الخيارات الأثيوبية في التنمية وبنـاء

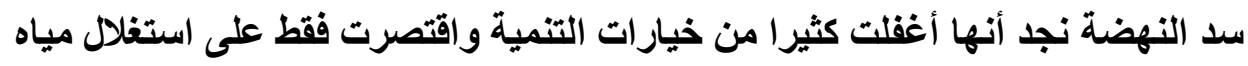
نهر النيل في ملء خزان سد النهضة بدون موافقة دول المصب ودول المجرى الأوسط

ثالثًا : الأولوية الاستراتيجية الثالثة: " هعالجة السدود القائمة ".

يعتمد التنفيذ الفعال لهذه الأولوية الاستراتيجية على تطبيق هذه المبادئ: 1- الرصد الثشامل بعد انتهاء المشروع وعملية التقييم، ووضع نظام للاستعراضـات

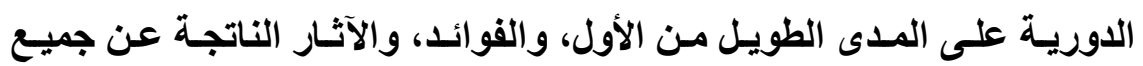
السدود الموجودة والقائمة التي تم تقديمها.

(1) Dams and development - Op.cit - p 221 
ץ - برامج لاستعادة وتحسين وتعظيم الفوائد مـن السدود الكبيرة القائمـة التي تـم تحديدها وتنفيذها، والخيارات المسأخوذة في الاعتبار التي تشمل إعـادة التأهيل والتحديث وترقية المعدات والمرافق، وتحسين عمليات التخزين، واستعراض التهي التدابير غير الهيكيلية لتحسين كفاءة استلام واستخدام الخدمات. r- تمبيز القضايا الاجتماعية المرتبطة بالسدود الكبيرة القائمة المحددة، والمقررة، ووضـع العمليـات والآليـات وتطوير هـا بمـا يتناسب مـع المجتمعـات المتضررة ل لعلاجها.

ع ـ فعالية تدابير التخفيف البيئية القائمة ، وتقييم وتحديد التأثيرات غير المتوقعة ، والفرص المتاحة للتخفيف والاستعادة وتعزيز ماهو قائم. هـ لاى جميع السدود الكبيرة اتفاقيات تثنغيل رسمية بفترات ترخيص زمنيـة؛ حيث تثير عمليات إعادة التخطيط أو إعادة الترخيص أن التغيرات الهيكيلية للمرافق

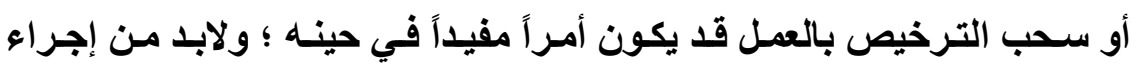
دراسة جدوى اقتصادية كاملة وتقييم للأثر البيئي والاجتماعي. (') لمئل وبتطبيق هذه الأولوية على نشاطات أثيوبيا نجد أن المعلومات التي يتم تسريبها أو الإفصاح عنها بخصوص سـ النهضة توحي بعدم مصداقية التقيـيم الفعلي لبنـاء السد، وأن من جملة آثاره حبس المياه عن دول المصب ممـا قد يحدو بها إلى الجفـاف والقحط، والتصحر فضلا عن انتثار الأوبئة والمجاعات بين سكان ضفتي مجرى نهر 


\section{رابعًا : الأولوية الاستراتيجية الرابعة ” الهفاظ على الأنهار وسبل العيش ”.}

يعتمد التنفيذ الفعال لهذه الأولوية الاستراتيجية على تطبيق هذه المبادئ الآتية:

1ـ فهم وظائف النظم الايكولوجية لنطاق الحوض، والقيم والمنطلبات وكيف يعتمد

المجتمع البشري في معيشته عليها وكيف سيتأثر بالسد، كل ذلك من الأمور

$$
\text { المتطلبة قبل اتخاذ قرارات بشأن خيارات التنمية. }
$$

r - لابد من الأخذ في الاعتبار قرارت النظم الايكولوجية والاجتماعية وقضايا الصحة

باعتبارها جزءاً لا يتجزأ من المشروع وتنمية حوض النهر، وتحديد الأولويات

لتجنب الآثار الجانبية الضارة وفقا للنهج التحوطي.

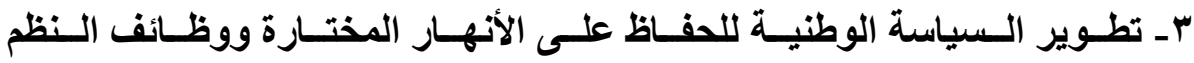

الايكولوجيـة العاليـة والقيم في حالتها الطبيعيـة عند استعراض مواقع بديلـة

للسدود على الأنهار غير المطورة، وإعطاء الأولوية للمواقع على روافدها.

عـ يتم اختيار وتحديد خيارات المشروع التي تتجنب التأثيرات الكبيرة التعويضية

القابلة للحدوث توضع في موضع يؤدي إلى منفعة وفائدة صافية لهذه الأنواع

في المنطقة.

هـ السدود الكبيرة التي توفر إخراج عن التدفقات البيئية للمساعدة في الحفاظ على سلامة النظم الايكولوجية لدول المصب وسبل العيش لقاطني هذه الدول؛ فيجب ألون

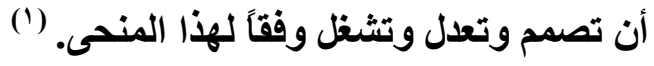

(1) Dams and development - Op.cit - p 234 
وبتطبيق هذه الأولوية على ممارسات أثيوبيا نجد أن بناء السد سيؤدي إلى هدر

كبير في مياه النيل نظرأ لعدم قدرة جسم السد وخزانه على احتمال المياه خلفه محتجزة نظراً لبناءه على هضبة عالية مما يبشر بإمكانية انهياره في أي لحظة وستهر جميع المياه خلفه لتغرق دول المجرى الأوسط للنهر ودول المصب. خاهسًا : الأولوية الاستراتيجية الخاهسة: ” الاعتراف بالهقوق التاريخية وتقاسم

\section{الإنفافع}

يعتمد التنفيذ الفعال لهذه الأولوية الاستراتيجية على تطبيق هذه المبادئ:

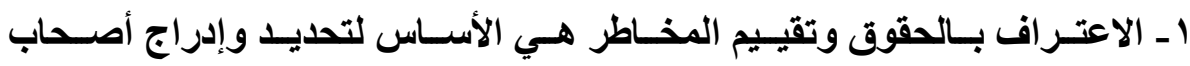

المـصلحة المتـأثرين بالسلب في مفاوضسات مسشتركة حـول التخفيـف و إعـادة

التوطين والتنمية، واتخاذ القرارت بشأن كل هذا.

r - يشمل تقييم الآثار جميع الأفراد في دول خزان السد، والأفراد في دولـة المنبع،

والأفراد في دولـة المصب، ومنـاطق مستجمعات الميـاه التـي خصائسهرا في

العيش والموارد غير المادية سوف تتضرر من ذلك السد، ويشمل ذلك أيضا

أولئك الذين تتـأثر بنيتهم التحتيـة بسبب بنـاء السد وخطوط النقل والقـوات

$$
\text { وتطورات إعادة التوطين. }
$$

r- جميع الأشخاص المتضررين المعترف بهم لهم الدق في التفاوض المتفق عليه

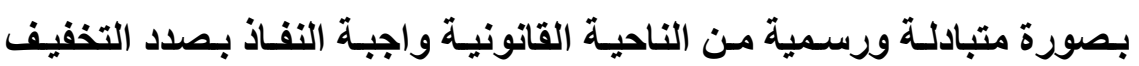

وإعادة التوطين واستحقاقات التنمية. 


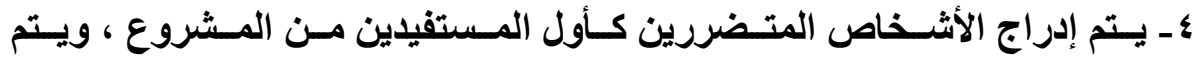

التفـاوض للضمان التنفيـذ بخصوص عمليـات التقاسـم للمنـافع للاتفـاق عليها

بصورة قانونية متبادلة وفق ما يحميه القانون. (')

وبتطبيق هذه الأولويـة نؤكد على أن لمصر والسودان حق تـاريخي في حصة

مياه النيل التي تصل إلى كليهما تتناسب ونشاطات السكان في كل منهمـا، وهذا الحق التاريخي يشكل قاعدة عرفية دولية ملزمة كما أسلقنا ذكره آنفا.

سادسكًا : الأولوية الاستراتيجية السادسة: ” ضمان الاهتثال ". يعتمد التنفيذ الفعال لهذه الأولوية الاستراتيجية على تطبيق هذه المبادئ:

ا - يتم إعادة مجموعة واضحة ومتسقة ومشتركة من المعايير والمبادئ التوجيهية

التـي تـضمن الامتثـال ، ويـتم ذلــك مـن خـلال مؤسـسـات المقـاولات والتمويـل

والرعاة، ويخضع ضمان الامتثال لمراجعة مستقلة وشفافة.

بـ يـتم إعداد خطة للامتثنال للمشروع قبل البدء فيـه، توضـح فيها كيف سيتحقى

الامتثال للمعـايير والمبـادئ التوجيهيـة ذات الصلة، وتحدد الترتيبـات الملزمـة

للمشروع، والالتزامات الفنية والاجتماعية والبيئية المحددة.

rـ تحديد تكاليف إنشاء آليات الامتثال والقدرات المؤسسية المتصلة بها، وتطبيقها

تطبيقًا فعالاً ويوضح ذلك في ميزانية المشروع.

(1) Dams and development - Op.cit - p 240 
ــ تجنب الممارسات الفاسدة من خلال تنفيذ التشريعات والمواثيق طواعية وبحسن

هـ الحوافز التي يلتزم بها أنصار المشروع وفقا للمعايير والمبادئ التوجيهية يتم

تطوير ها من جانب المؤسسات المالية العامة والخاصة. (1)

وبتطبيق هذه الأولويـة على مـدى امتثـال أثيوبيـا للقواعد الدوليـة والمعـيير

المتبعة في بناء السدود الكبيرة نجد عدم امتثال واضح لأثيوبيا في الالتزام بهذه القواعد الدولية والمعايير التي يجب اتباعها في بناء وتثشغيل السدود.

سابعًا : الأولوية الاستراتيمية السابعة: " تقاسم الأنهار لأجل السلامم والتنهمية

يعتمد التفيذ الفعال لهذه الأولوية الاستراتيجية على تطبيق هذه المبادئ:

ا ـ سياسـات الميـاه الوطنيـة تحـد حكماً لاتفاقيـات الحـوض في أحسواض الأنهـار

المشتركة، ويتم التفـاوض على الاتفاقـات على أسـاس حسن النيـة بين الدول

المتثاطئة، وهي تستند إلى مبادئ الإنصاف والاستخدام المعقول وعدم إحداث

ضرر جوهري، والمعلومات المسبقة، والأولويات الاستراتيجية المحددة من قبل

لجنة السدود الاولية.

r- لابد أن تتجاوز الدول المشاطئة للنهر النظر بشكل قاصر إلى المساء فقط ؛ حيث

تلتزم بضرورة تبني نهج التقاسم وبشكل عـادل ولكن ليس للمساء فقط، وإنمـا

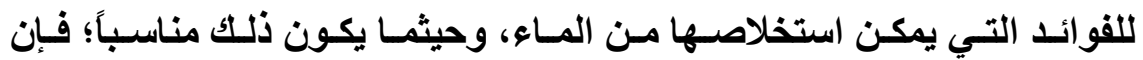

(1) Dams and development - Op.cit - p 244 
المفاوضـات ستششمل الفوائسد خـارج حوض النهر وغيرهـا مـن القطاعـات ذات

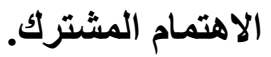

r- لا تبني السدود على الأنهار المشتركة في الحـالات التي تثير الدول المشاطئة اعتراضا يؤيد من قبل لجنة مستقلة، حيث أن النزاعات المستعصية يتم حلها بين الدول من خلال مختلف وسائل النزاع بما في ذلك وفي المقام الأخير محكمة

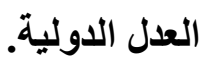

ع ـ لتطوير المشاريع على الأنهار المشتركة بين الوحدات السياسية داخل الدول يتم توفير البنيان التشريعي اللازم على الصعيدين الوطنى وما دون الوطني لتجسيد الأولويات الاستراتيجية للجنة السدود الدولية من كسب القبول العام، والاعتراف بالاستحقاقات التاريخية والحفاظ على الأنهار وسبل العيش. هـ حينمـا تخطط الحكومـات أو تسهل بنـاء السد على نهر مشترك بالمخالفة لمبدأ المفاوضات بحسن نية بين الدول المشاطئة، فعلى هيئات التمويل الخـارجي أن تسحب دعمها للمشاريع والبرامج التي تروج لها هذه الحكومة. (') ومما سبق نخلص إلى أن أثيوبيا وفقا للأولويات الاستراتيجية التي تبنتها لجنة السدود الدولية قد أغقلت أغلب بـل كل القواعد والمعايير الدوليـة المتبعة في بنـاء السدود الكبيرة، وهذا يجيب على تساؤلنا بخصوص القواعد التي يجب مراعاتها في بناء السدود الكبيزة على الأنهار الدولية، وقواعد ملع الخزانـات الخاصـة بهاوانتهينـا إلى عدم جواز بناء السدود الكبيرة على منـابع الأنهار الدولية نظرا للأضرار المؤكدة 
التي سوف تتحقق على إثر ذلك البنـاء، وأن في فترة ملع خزانـات السدود لابد من مراعاة احتياجات دول المجرى الأوسط للنهز ودول المصب من الميـاه المحتجزة خلف السد لأن ذلك أضحى لها حقاً تاريخيا لا يجوز لأحد الاعتداء عليه. 


\title{
المبـث الثاني \\ احترام الحقوق التاريخية المكتسبة
}

هن قبيل الاقتسام العادل (المعقول والمنصف) لمياه نهر النيل

\author{
إثـارة لمسا سـلف ذكره في تقرير لجنة السدود الكبيرة حول احترام الحقوق

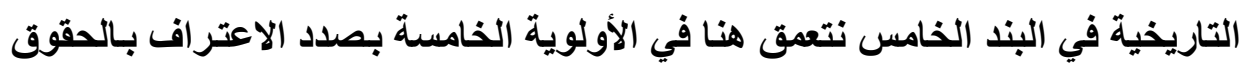 \\ التاريخية وتقاسم المنافع. \\ المطاب الأول
}

احترام الحقوق المكتسبة قاعدة عرفية دولية

يعد احترام الحقوق المكتسبة قاعدة عرفية جرى عليها العمل الدولي ، وهذه

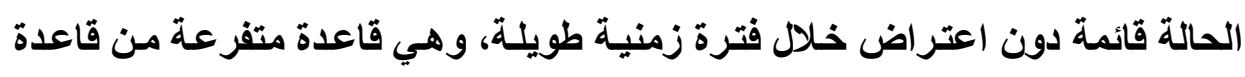

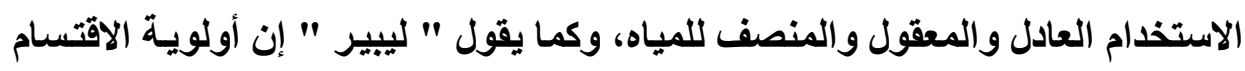

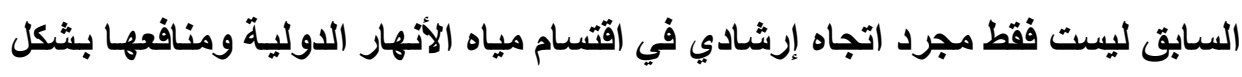

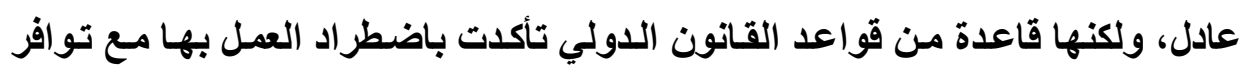

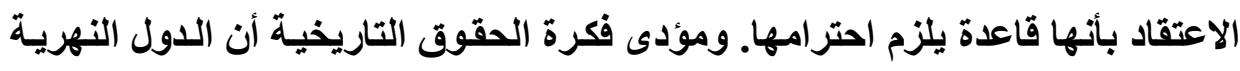

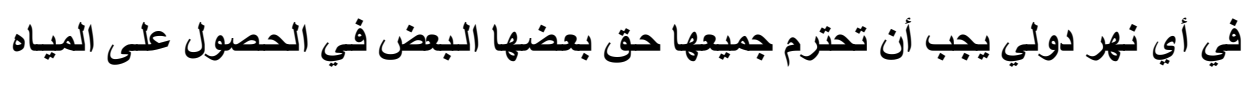

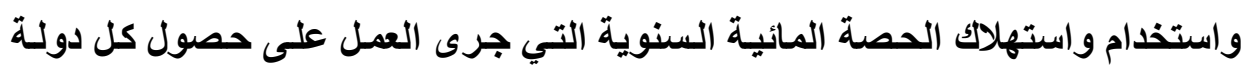


عليها على مر السنين السابقة؛ إذ أن تلك الحصص تعبر في الواقع عن أسلوب الانتفاع العادل الذي ارتضته الدول المشاطئة لتوزيع حصص ميـاه النهر الدولي على مدار

التاريخ؛ لذا تسمى هذه الحقوق بالحقوق التاريخية. (')

\section{أولاً : شروط اكتساب الهقوق التاريخية}

قد حرصت غالبيـة الدول على النص على وجوب المحافظة على الحصص القليمة التي كانت تحصل عليها كل منها ، ويثترط القانون الدولي العرفي توافر ثلاثة

$$
\text { شروط لاكتساب الحق التاريخي وهي: }
$$

1 - وجود ممارسة ظاهرة ومستمرة يقابلها موقف سلبي من جانب الدول الأخرى.

r- أن يستمر هذا الموقف السلبي طوال فترة زمنية كافية لاستخلاص قرينة. ץ- وجود ما يسمى بالتسامح العام من جانب الدول الأخرى أو التسليم وهو رضـاء

$$
\text { سلبي. (") }
$$

\section{ثانيا : تكاهل الصالح الاقتصادية والحقوق المكتسبة}

يعد المجرى المائي عبارة عن مصالح اقتصادية أو مجموعة مصالح مشتركة

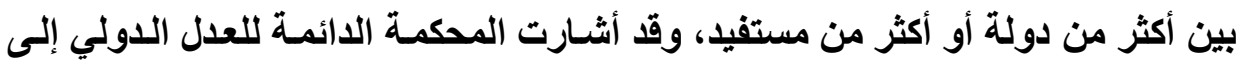

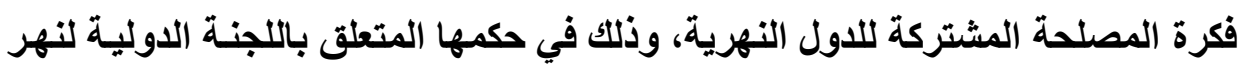

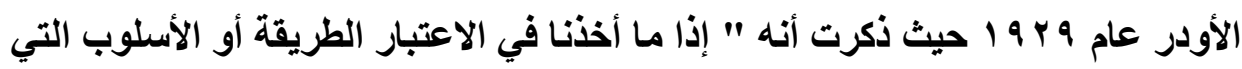

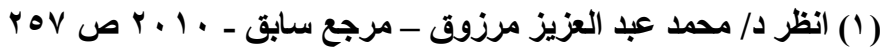

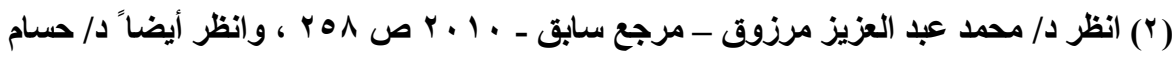

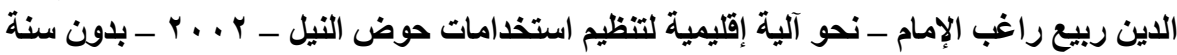

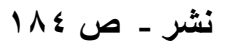


تعامل بها الدول الأوضاع الواقعية الناجمة عن جريان مجرى الماء عبر أو بجانب إقليم العديـ من الدول ، وإمكاتيـة اشباع احتياجاتها العادلة، واعتبـارات المنفعة الواضحة بداهـة من هذا الواقع فإنتا سندرك فوراً أن حل المشكلة لا يبحث عنه في فكرة حق المرور لصالح دول المنبع ، وإنما البحث عنها يكون في جماعية المصالح أو عمومية المصالح بالنسبة للاول النهرية" فالغاية الاقتصادية وهي الاستفادة المادية إلى أقصى حد ممكن من المجرى واستعماله كأداة من أدوات النمو الاقتصادي لا تعني التقليل من الت التص

القواعد القانونية المكتسبة وإنما يتكامل كل منهم مع الآخر. (1)

\section{ثالثًاً : دلالة الهقوق التاريخية}

حمايـة الحقوق التاريخية أو الاتقسام السابق لميـاه نهر دولي معين لـم تثقرر لمجرد الارتكاز إلى الأمر الواقع، ولكنها قررت تحقيقـا لاستقرار الأوضساع الاقتصاية والاجتماعية السائدة على ضفاف الأنهار الدولية، وذلك لأن هذه الحقوق غالبا ما تثكل أساسـا ثابتا للبناء الاقتصادي والاجتمـاعي للاول النهريـة وعلى الأخص في حضارات الأنهار. إذ تعتمـد هذه الحضارات منـذ القدم وبصفة دائمسة على مـا اعتـاد السكان أن يحصلوا عليه سنوياً من المياه ، ويتفق ذلك مـع مبدأ حسن الجوار ويؤدي ذلك إلى استقرار السلم والأمن الدوليين. () ويستخدم اصطلاح الحقوق التاريخيـة للالالـة على السند التـاريخي المخـالف للقانون والأي تدعي الدولة بمقتضاه اختصاصاً غير قانوني من حيث الأصل، ولكن رضاء الجماعة الدولية بهذا الاختصاص يحول السند التاريخي إلى سند قانوني صحيح

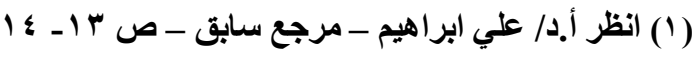

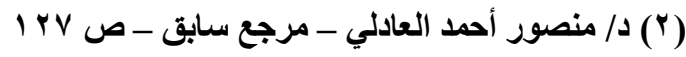


نتيجـة لهـذا الاذعـان والرضـاء. ومـن ثم يستعمل تعبير الحقوق التاريخيـة ليدل على الحقوق التي تكتسب مخالفة لأحكام القانون الدولي عن طريق ممارسـة تاريخيـة تؤكد بها دولة ما اختصاصاً لها هو في الأصل غير مشروع، إذ لم يجر اعتراض على هذه الممارسة. فالحق التاريخي في مياه الحوض هو ولاية معينة لاولة ما في أن تحصل أو تستعمل أو تحول كمية من المياه تتبع من مصدر معين سواء كان نهراً أم بحيرة أم مياه جوفية وأن تحافظ على الحصول على تلك الكميـة سنوياً وللأبـد وفقاً لمـا جرى عليه التوزيع السابق والمستقر طالما بقيت الظروف والأوضساع على حالها.وتتمسك مصر بحقوقهـا التاريخيـة في ميـاه النيـل، وفي عـام 9 ج 9 ا اتفقت الحكومتـان المـصرية والبريطانيـة على حمايـة حقوق مصر الطبيعية والتاريخيـة في ميـاه النيل طبقاً لمبـأ أسبقية الاستغلال ، وحمايـة أوجـه الاستغلال المستقبلة في مصر تباعـاً لزيـادة عدد السكان. فقد جـاء في المـكرات المتبادلـة بين مسر وبريطانيـا، وفي مـذكرة وزارة الخارجية البريطانية إلى ممثلها اللورد " لويد " المبدأ المقبول أن ميـاه النيل، والذي يعني ما هو مفاده ( مجموع تدفق الأبيض والأزرق وروافد النيل ) يجب أن تعتبر وحدة واحدة لاستخدامها من قبل الثعب في مصر والسودان وفقاً لاحتياجاتها وقدرتها على الاستفادة منهـا، وطبقاً لهذا المبـأ تعترف بحق مصر الطبيعي والتـاريخي في هذه الإمدادات من المياه لمناطق تخضع حالياً للزراعة، ونصف أي إمدادات إضافية تتاح في المستقبل. - المست.

لذلك رفضت مصر التوقيع على اتفاقية الإطار القانوني لمبادرة حوض النيل إلا

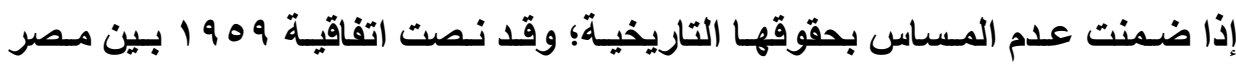
والسودان على أنها: " يكون مـا تستخدمه الجمهوريـة العربية المتحدة من مياه نهر النيل حتى توقيع هذا الاتفاق هو الحق المكتسب لها قبل الحصول على الفوائد التي 
سيحققها ضبط النهز وزيادة إيراده، ومقدار هذا الحق ^ ؛ مليار متر مكعب سنوياً ؛ ويكون مـا تستخدمه جمهوريـة السودان في الوقت الحاضر هو حقها المكتسب قبل الحصول على فائدة المشروعات المشار إليها، ومقدار هذا الحق أربعة مليارات من الأمتار المكعبة مقدرة عند أسوان سنوياً. (1)

وتبرر هذه القاعدة العرفيـة بـأن هؤلاء السكان قد اعتـادوا على حيـاة معينـة

قوامها مياه النهر، وما يتفرع عنها من فوائد في كل شيء ، وأي تغير في هذه الكمية نحو القلة يؤدي إلى حدوث اضطراب في حياتهم المستقرة مما يؤدي إلى الاحتكاك مـع شـوب أخرى مجاورة جـارت على حقوقهم التاريخيـة، فـالتوزيع السـابق للميـاه يجب احترامه والمحافظة عليه ؛ لأن مرور الوقت الطويل على هذا التوزيع ورضساء الدول الثاطئية الأخرى به يعبر عن المساواة والتوزيع العادل والمنصف(؟) لهذه المياه يشكل أسـاسـاً للبنـاء الاقتصادي والاجتمـاعي لهذه المجتمعـات الزراعيـة فهي قاعدة عرفية هدفها خدمة السلام والاستقرار.

\section{رابعًا : الفارق بين الحقوق التاريخية والحقوق المكتسبة}

يجب أن نفرق بين الحقوق التاريخية والحقوق المكتسبة ، حيث يستعمل تعبير

الحقوق التاريخية ليال على الحقوق التي تكتسب مخالفة لأحكام القانون الدولي عن

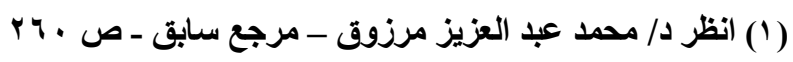

(') Assef M. Melesse - Op.cit - p 409 " The future for such cooperation in the basin will depend on the acceptance of benefit sharing over water sharing as guiding principle by the countries in the basin and also in recognizing " equitable and reasonable " allocations along with historical precedence of water usage." 
طريق ممارسة تاريخية تؤكد بها دولة ما اختصاصاً لها هو في الأصل غير مشروع، إذ

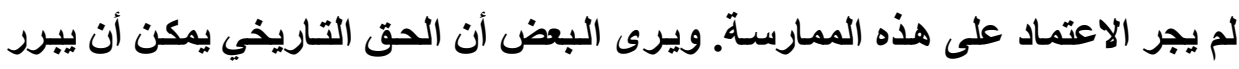

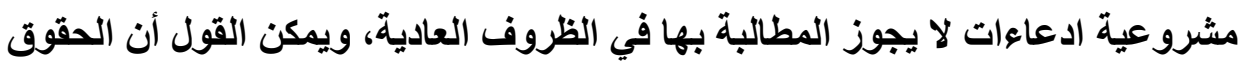

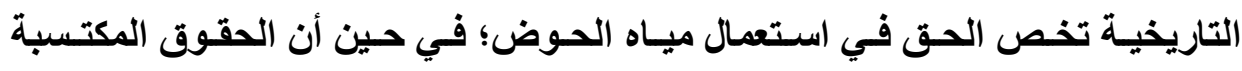
تنصرف إلى كمية المياه المستخدمة وإلى أوجها استغلال هذه المياه، كمـا أن الاقتسام

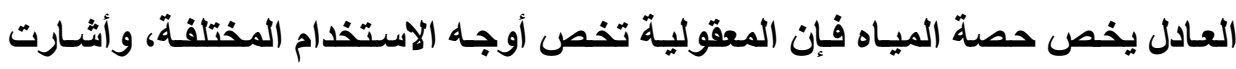

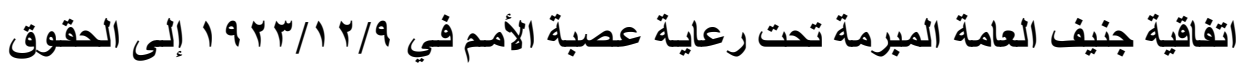
المكتسبة في المادة ץ " يجب أن يولى الاعتبار إلى الاستخدام السابق ".(') وقد سعت مبادرة حوض النيل (†) إلى جمع دول الحوض للتشاور وفهم معطيات

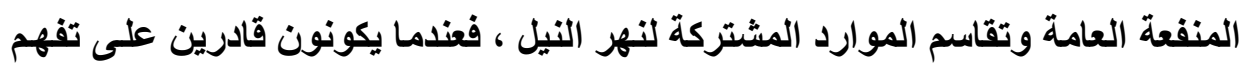
الاختلافات في الاستخدامات وأوجه الانتفاع من المورد المشترك ، وأن مـا ينفع دولية المنبع قد لا ينفع دولة المصب ، فقد توصلت بعض دول الحوض إلى اتفاقات ذات نتائج

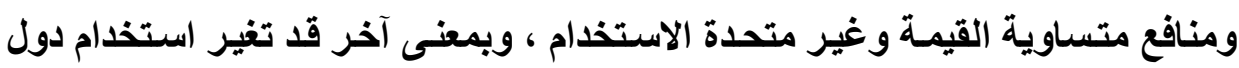
حوض النيل للانتفاع بمياه الحوض من حصص متساوية إلى تقاسم لمنافع النيل رغم عدم تساوي الحصص . (") 


\section{خاهسًا : عواهل تساهم في ضهان المساواة بين الدول الذهرية}

يتعين على دول المجرى المـائي أن تأخذ بعين الاعتبار بصفة مستمرة جميع العوامل ذات الصلة التي هي ضمان للحقوق المتساوية لدول المجرى المسائي والتي

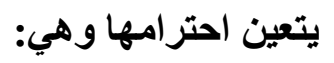

أ) العوامـل الجغرافيـة والهيلروغرافيـة والهيلرولوجيـة والمناخيـة والايكولوجيـة و العو امل الأخرى التي لها صفة طبيعية.

وهي العوامل التي تساهم في تكوين وتحديد حجم المياه و إمداداتها وذلك من خلال الدولة الهيدرولوجية للمياه؛ فالامتداد الجغرافي للمياه داخل إقليم كل دولة ومدىى إسـهام الاولـة في كميـات الميـاه تعد مـن المعسيير الأساسية لتحديد الاستخدام (') المنصف. ب) الحاجات الاجتماعية والاقتصادية لدول المجرى المائي المعنية وهي حاجات تتحدد وفقاً لأحكام القانون الاولئي. يبذو ضروريا قبل الشروع في إجراء تقاسم المياه الأخذ بعين الاعتبار الحاجـات

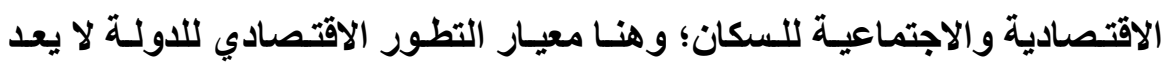

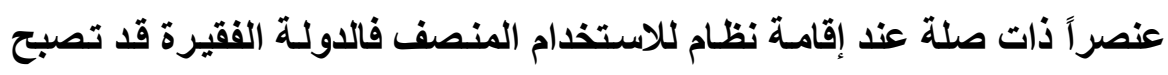
غنية لاكتثاف مصادر وموارد طبيعية جديدة، كما أن المقارنة بين درجة التطور

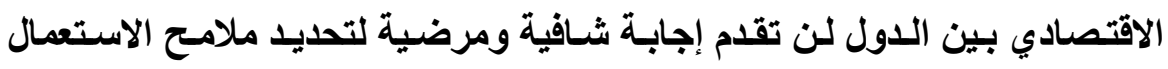
المنصف، ومسن ثم يعد القرار اللذي يمنح الدول الفقيرة مزايـا إضـافية قرارا

$$
\text { (1) انظر د/ محمد عبد العزيز مرزوق - مرجع سابق - ص ابT }
$$


سياسيا ، وأن الاحتياجات الاقتصادية كعنصر من العناصر التي تؤخذ في الاعتبار لا يعنـي المقارنـة بين مستويات التطور الاقتصـادي والاجتمـاعي للـدول المعنيـة. ويتلخص مراعاة تلكك الحاجات وفق المبادئ الآتية: 1 أية دولة من دول الحوض لا تملكك مـا تستخدمه من مياه الحوض، وإنمـا لها حق الاسـتغلال فقط ؛ ذلــك أن ملكيـة الميـاه هـي ملكيـة مسشتركة لكـل دول الحوض، فسلطات الدولة على مجرى النهر الدولي هي سلطة مقيدة بشرط عدم الإضرار بباقي دول حوض النهر، وبضرورة الاتفـاق بشأن أي استغلال ينال من حقوق الآخرين. r ـ لكل دولـة نهريـة الحق في استغلال الميـاه الجاريـة في إقليمهـا تطبيقاً لمبـأ السيادة الإقليمية، ولكن لما كاتت كل دولة قائمة على نفس المجرى لها حق متساو في استغلال هذه الميـاه ، فِان كل منهـا مقيد بحقوق الدول الأخرى

$$
\text { الواقعة في ذات المجرى. }
$$

rـ إذا كان هناك فائض في المياه يمكن التفضل بـه على أحد ، فبان دول الحوض أحق به من تلك التي تقع خارج الحوض.

ع ـ توزيع المياه بين دول الحوض قد تم بناء على الاحتياجات الاقتصادية الفعلية، فإذا كانت حصة دولة من دول الحوض تفيض عن حاجتها بالقدر الذي يسمح بتحويـلـل جـزء منهــا إلـى دولـة خـارج دول الحـوض؛ فـإن التوزيــع العـادل والمنصف يكون قـ انهار. هـ إذا تبـين لـدول الحـوض أن دولـة مـن دول الحـوض قـ غالـت فـي تقـديرات احتياجاتها الحاضرة أو المستقبلة من ميـاه الحوض، أو إن إمكانـات التوسع 
الزراعي لا تسمح باستخدام كل حصتها، أو أن للايها فائض من المياه يزيـا عن حاجتها يجعلها تسرف أو تفرط في مـا لليها من مياه، فيكون لكل دول الحوض الحق في طلب إعادة النظر في تقسيم حصص المياه. צـ لحماية الحق المكتسب يشترط أن يكون الاستغلال نافعاً ومفيداً ومعقولاً، ومن ثم لا يمكن لدولـة مـن دول الحوض أن تدعي بـأن حقها المكتسب في ميـاه الحوض يخول لهـا إن هي أرادت أن تثرك حصتها المائيـة تضيع في البحر

$$
\text { هدراً أو تمد بها غير ها من الدول خارج الحوض. }
$$

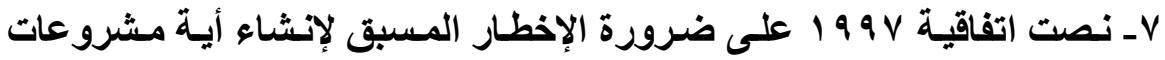
جديدة، ومن ثم فـالمجتمع الدولي يرفض بشدة فكرة أن للاولـة الحق الكامل في أن تمـارس سـيادة مطلقة على جزء المجرى المسائي الدولي الذي يمر

$$
\text { بإقليمها دون قيد أو شرط. }
$$

^ـ تتحدد الحصة المعقولة والمنصفة للمياه وفقا لاحتياجـات كل دولة وفي ضوء الظروف التاريخية والجغرافية والاقتصادية لكل دولة ، فمعنى التقسيم العادل والمعقول ألا تستحق كل دولـة مـن دول المجرى إلا نـصيبًا مـن الميـاه يتفق واحتياجاتها التي يتم تحدياها على أسس ثابتة مثل مساحة الإقليم المزروعة، أو القابلة للزراعة وتعداد السكان الذين يعتمدون على تلكك المياه، فإذا كـان هناك فائض في حصة دولة ما من دول الحوض تريد أن تمد بـه دولـة ليست من دول الحوض ؛ فمعنى ذلك أن التقسيم لم يكن عادلاً ومعقولاً، ويحق لباقي 
دول الحوض أن تطلب إعـادة التوزيع طبقاً لقاعدة الانتفـاع العـادل والمعقول

$$
\text { لمياه الحوض. (') }
$$

ج) السكان الذين يعتمدون على المجرى المائي في كل دولة من دول المجرى المائي. فلابد أن يؤخذ في الاعتبار عدد السكان ودرجة اعتمـادهم على الميـاه ، وضرورة مراعاة عدد السكان في كل دولة من الدول التي تعثمد على ميـاه النهر أكثر من غيرها ، فالدول التي عدد سكانها ، . . مليون لا يمكن أن نعاملها معاملة الدول التي يبلغ عدد سكانها خمسة ملايين فقط. ولهذا المعيار قبول في القضاء الفدرالي الأمريكي ، فقي النزاع الخاص بمياه نهر (نير مـادا) () أكدات المحكمة المختصة على أن "عدد سكان الولايـات المعتمدين على إمدادات الميـاه ودرجة اعتمـادهم" تشكل عنصراً يلزمم مراعاتـه عند إجراء التوزيع المنصف لمياه النهر.

وفي تقسيم المياه بين مصر والسودان في اتفاقية وه 9 19 كان عدد السكان في البلاين محل اعتبار حيث طالب الوفد السوداني أن تكون حصة السودان عبارة عن نسبة مئويـة من التدفق السنوي على أسساس نسبة التوزيع النسبي لسكان

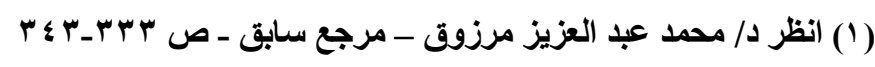

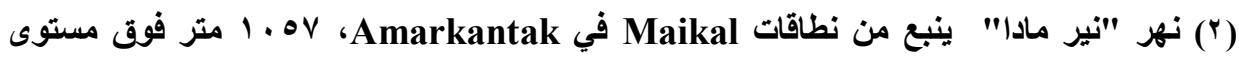

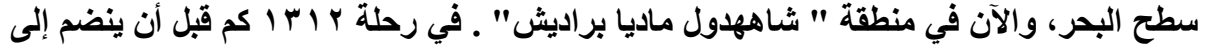

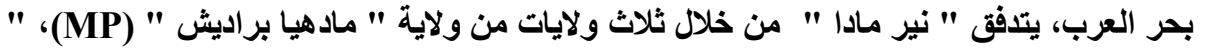

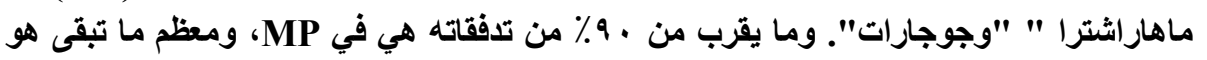

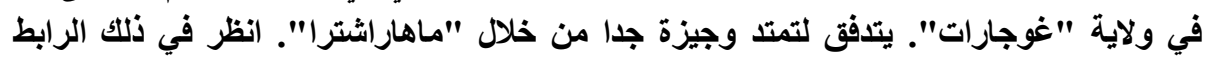

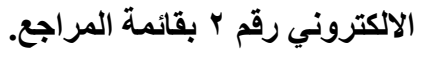


مصر والسودان على اعتبار أن سكان السودان نصف سكان مصر، واعترض الجانب المصري وطلب أن يكون نصيب كل من البلدين من الميـاه محدداً على أساس المعدلات الناتجة عن تطبيق الافتراضيين التاليين. الأول/ إجراء تعداد سكان عام في كل من البلدين. الثاني/ اللجوء إلى الأسـاليب المستخدمة في مصر عندما تقيـ الاحتياجـات من الميـاه اللازمــة للأراضـي الزراعيـة الجديـدة التـي تستــلح في كـل مـن مـصر

$$
\text { والسودان(') }
$$

د) آثـار اسـتخدامـات المجـرى المسائي في إحدى دول المجرى على غيرهـا مسن دول المجرى المائي وهذا الأمر ناتج عن اعتبار المجرى المائي الدولي كلاً واحداً ، حيث يشكل الضرر النـاجم عن اسـتمرارية الاستخدامات الحاليـة وحرمسان الـدول المعنيـة مـن إنشاء استخدامات جديدة، أحد العناصر الهامـة في هذا الإطـار ، ولإعمـال هذا العنصر يجب بدء تحديد طبيعة الضرر ومداه. ومن ثم يستخدم هذا العامل لتطبيق مبدأ الاستخدام المنصف بطريقة إيجابيـة في التعرف على مدى تحقيقهـ للاحتياجـات الاقتصادية والاجتماعية والاعتبارات البيئية في الدولة التي يُزمـع استخدامها أو مباشرتها بالفعل. وبطريقـة سلبية في التعرف على مـا ينطوي عليه الاستخدام الحسالي أو الاسـتخدام المستقبلي مسن آثـار سـلبية على الاحتياجـات الاقتـصاية والاجتماعية والاعتبارات البيئية في الدول المشتركة في المياه العابرة للحدود. 


\section{هـ) الاستخدامات القائمة والمحتملة للمجرى المائي}

المـادة السـادسة مـن اتفاقيـة الأمـم المتحـدة و9 9 النصت على أن الاسـتخدامات القائمة والمحتملة للمجرى المائي من العوامل ذات الصلة بالانتفاع العادل، ونصت المـادة الخامسة من قواعد هلسنكي على أهمية مراعـاة الانتفـاع السابق بميـاه الحوض، وجاءت المادة السابعة من قواعد هلسنكي تؤكد ذلك حيث نصت على أنه " لا يجوز منع أية دولة من دول الحوض عن استخدام حوض صرف دولسي على النحـو المناسـب القـائم بحجـة الاحتفــاظ لاولــة أخرى مسشاركة في الحوض لحق استخدام تلك الميـاه مستقبلاً". وأن الاستخدامـات المحتملة أو المستقبلية تشكل أحد العناصـر ذات الصلة والتي تؤخذ في الاعتبـار عنــ تحديــ مـدى انتصاف معقولية استخدام ما.وهذه العوامل السابقة هي عوامل غير نهائية ؛ فمـا هي إلا عوامل إرشادية لا تحول دون مر اعاة ظروف وطبيعة كل نهر على حده. و- حفظ الموارد المائية للمجرى المائي وحمايتها وتنميتها والاقتصاد في استخدامها وتكاليف التدابير المتخذة في هذ الصدد الحماية الكافية تثمل الإجراعات المتصلة بعملية الحفظ والأمن ومقاومة الأمراض المنقولة بواسطة المياه، وإجراءات الإشراف القني مثل تلكك الإجراءات المنفذة من أجل تنظيم المجرى المجرى أو مقاومـة الفيضانـات ومكافحة التلوث والجفـاف أو دخول ميـاه مالحة نحو مجرى النهر من مصادر أخرى. وهذه الإجراءات يمكن تتفيذها بصورة فردية من جانب دولة واحدة كمـا يمكن تنفيذها بصورة جماعية وتعاونية بواسطة الدول المستفيدة من المجرى المائي الدولي. 
ز- مدى توافر بدائل ذات قيمة مقارنة لاستخدام مزمع أو قائم.

وهذا الأمر يتعلق بما إذا كـان هنـاك بـديل متـاح لاستخدام مزمـع أو استخدام قائم، وعما إذا كاتت هذه البدائل ذات قيمة تقابل الاستخدام المزمع أو الاستخدام القائم، وعما إذا كانت هذه البدائل كافيـة لإثباع الحاجـات القائمسة أو المزمعة، ولا تعني البـدائل فقط المـصـادر الأخـرى للميـاه، وإنمـــــل الوسـائل الأخـرى التـي تلبـي

الاحتياجات المذكورة كبدائل مصادر الطاقة أو النقل. (') 


\section{خاتمة البحث ( نتائج وتوصيات )}

قد عالجنا في الصفحات السابقة بناء السدود على الأنهار الدولية وحقوق مصر في مياه النيل ، والقواعد القانونية الدولية التي تنظم الانتفاع بمياه النيل، وقد اتبعت في بحثي منهجـاً تحليلياً استقيت فيـه القواعد والمبـادئ القانونيـة الدوليـة من مصادرها وصولاً لإطار عام يحكم استخدام نهر النيل تاريخياً من الناحية القانونية، ودراسة فقهية تصدت لاستخدام المجاري المائية الدولية في غير الأغراض الملاحية؛ وقد توصلت في نهايـة بحثي إلى ضرورة الاستناد لقواعد القـانون الدولي التي تحمي للدول النهريـة حقوقها؛ لما تتسم به من عدالة وإنصاف ، وخلصت فيه إلى النتائج والتوصيات التالية:

\section{" النتائج}

ا - ينبغي مراعـاة أوجـه الانتفـاع التي تناسب دول المنبع، ودول المجرى الأوسط للنهر، ودول المـصب، فــا يناسـب إحـاها قــ لا يناسب الأخرى، وذلـك عنــ التفاوض بين دول الحوض حول المشروعات المستقبلية على مجرى النهر. ولا يجـوز إجـراء أيـة أعمـال أو إجراءات على النهر إلا بعد التشـاور وفي حدود الالتزام بكميات المياه التي تصل لكل دولة ؛ أي عدم الإضرار بأي دولة من دول النهر من جراء استخدامه لمياه الحوض الموجودة بإقليمها ؛ خاصة حقوق دول المصب.ومن ثم تعد هذه الاتفاقات سنداً لمصر في الاحتفـاظ بحصتها في المياه المتدفقة على هضاب ومنابع النيل الأبيض والأزرق وروافدهما. r - لا يجوز لأثيوبيا الاحتكـام لمبدأ السجل النظيف للتصل من التزاماتها بحقوق مصر التاريخية في مياه النيل ، وذلك لأن أهم الاستتثاءات الواردة على مبدأ السجل النظيف هي احترام الاتفاقات ذات الطابع العيني. 
بـ تعتمـــ مـصر على حـق تـاريخي مكتسب مسن دول الاحـتلال الـسابق للأراضـي الأفريقية بحقها في مياه النيل وحصتها بشكل لابد من مراعاته عند أية مشاريع على حوض نهر النيل. ع ـ التوزيع العادل لمياه التهر والاقتسام المنصف لها. هـ لا يجوز لاولة يمر النهر الدولي بأراضيها أن ترتكب أي عمل من شـأنه الإضرار بحقوق الدول النهرية الأخرى على مجرى النهر الدولي. צـ عدم إجراء أي تحويل في مجرى النهر أو إقامة سدود عليه تنقص من حصة كل دولة نهرية على المجرى المـائي للنهر الدولي قد حصلت عليها وفقا لاتفاقية دولية سابقة أو وفقا لعرف جرى اتباعه مالم يتم الاتفاق على غير ذلك بين تلك

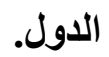
Vـ تعد نظريـة تقاسم المورد الطبيعي المشترك أساسـاً للاقتسام العـادل والمنصف للمياه كمبدأ أساسي في جلسات التفاوض بين الدول النهرية التي يجري بها نهر النيل وفق ما استقر عليه العمل والقضاء الدولي ومنها ( مبدأ العدالة في توزيع الميـاه والانتفاع المشترك، مبدأ الاستعمال البريء ، مبدأ الاستعمال المتكامل

$$
\text { للأنهار الدولية ). }
$$

^ـ تعد القرارات الصادرة عن معهد القانون الدولي ، وقواعد هلسنكي إطاراً عامـاً ملزماً، وقواعد عرفية دولية يجب مراعاتها عند إجراء أية مشاريع دولية على لئ

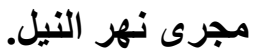
9- يعد بنـاء سـد النهضة وفقاً لمعـيير القـانون الدولي للمجـاري المائيـة الدوليـة، مخالفاً لما أقره من مبادئ وأسس قوامها عدم الإضرار بدول مجرى نهرالنيل خاصة دول المصب مصر والسودان؛ لما له من عيوب فنية بالغة الضرر. 
• 1 - يعد احترام الحقوق التاريخيـة المكتسبة مـن قبيل الاقتسام العـادل (المعقول

والمنـصف) لميـاه النيـل سـنـاً لمسصر في مفاوضـاتها مـع أثيوبيـا حـول ســـ

$$
\text { النهوضة. }
$$

\section{* التوصيات}

ا ـ نوصي المفـاوض المصري بالاحتكام لقواعد القـانون الدولي الاتفـاقي والعرفي الخاص بالمجاري المائية الدولية في الأغراض غير الملاحية، والأحكام القضائية الدولية الخاص بالمنازعات النهرية ، وذلك عند الجلوس على طاولـة المفاوضـات الخاصة بسد النهضة ، أو اللجوء إلى القضاء والتحكيم الدولي .

r - نوصي الدولة المصرية بضرورة التوجه إلى التنمية ومشاريع التطوير في دول القرن الأفريقي، ودول منـابع النيل سـياً للحفـاظ على الأمسن القومي المصري. خاصة بعد تنامي الاستفادة من تلك المشاريع النهرية ، ولأن ذلك يعد امتداد للأمن القومي المصري.

r- ضرورة تلريس حقوق مصر القانونية الدولية في مياه النيل في مراحل التعليم الأساسي ، والجامعات المصرية بغية توطين فكرة حق مصر التاريخي في مياه النيل وفقا لقواعد القانون الدولي.

$$
\text { WRR - world rivers review }
$$




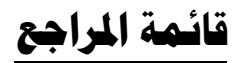

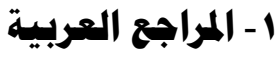

1ـ د/ حسام الدين ربيع راغب الإمام ـ نحو آلية إقليمية لتنظيم استخدامات حوض

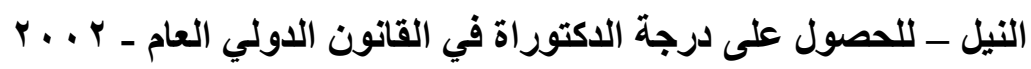

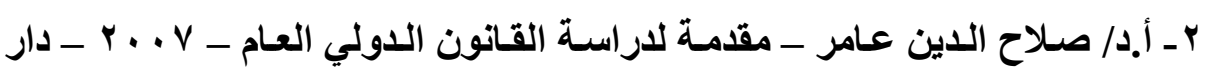

$$
\text { النهضة العربية }
$$

بـ أ.د/ عبد الهادي محمد عشري ـ التلوث النهري الدولي وتطبيقه على نهر النيل -

$$
\text { 1999 ـ ـ دار النهضة العربية - القاهرة. }
$$

ـ ـ أ.د/علي ابراهيم ـ قانون الأنهار و المجاري المائية الدولية ـ دار النهضة العربية

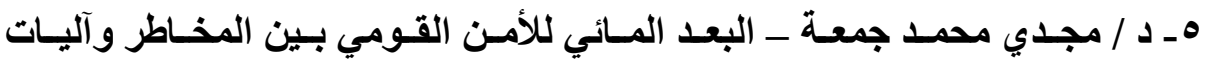

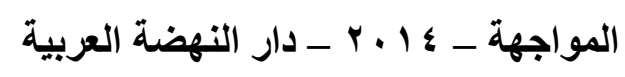

هـ د / محمد عبد العزيز مرزوق ـ مصر ودول حوض النيل - دراسة لقواعد القانون

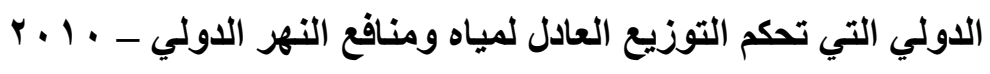

Vـ د/ محمود عبد المؤمن محفوظ محمد - حقوق مصر في مياه النيل في ضوء

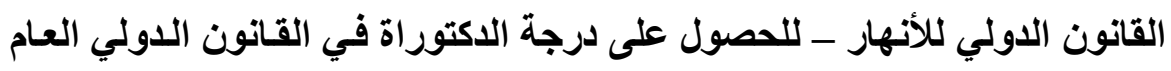

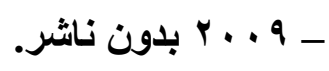


د/ أكرم مصطفى الزغبى

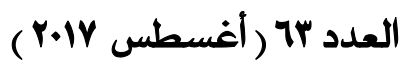

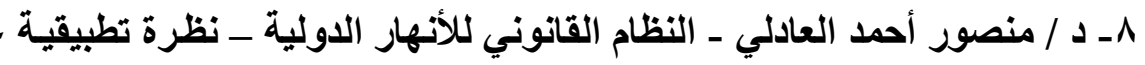

أهم أنهار الشرق الأوسط - رسـالة مقدمـة للحصول على درجـة الدكتوراة في

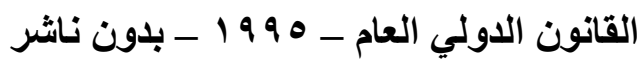

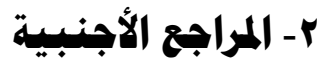

1 -Rami okascha - water scarcity and regional security in the Nile basin. - Grin publisher - 2013

2 - Assef M. Melesse - Nile river " Hydrology, climate and water use " - springer - 2011

3 - Dams and development A new framework for Decisionmaking : the report of the world commission on Dams November 2000 - Earthscan publications Ltd, London and sterling, VA

4 - Diana Rizzolio Karyabwite " water sharing in the Nile river valley - unep/dewa/grid- Geneva - January -March 1999 - January - June 2000 - project gnv011: using gis/remote sensing for the sustainable use of natural resources .

5 - Cari Meister - Nile river "- springer - 2010

6 - Bjorn lineman - Economy and transport in the Nile region - is the Nile a shaping element - Grin publisher - 2010 
7 - Haggai - Erlich the cross and the river Ethiopia, Egypt and the Nile - 2002 - Lyme Rienner publishers.

8 -Seleshi bekele Awulachew and others - The Nile river basin

- water - agriculture - governance and livelihoods - 2012

$$
\text { أ ألعربية: المقالات }
$$

$$
\begin{aligned}
& \text { 1ـ أ.د/ أحمد فوزي عبد المنعم ـ الالتزام بعدم التسبب في ضرر جوهري ـ المجلة }
\end{aligned}
$$

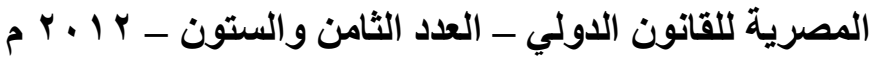

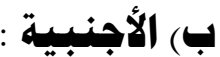

world rivers review - international rivers organization

- vol 27/ No 1 - March 2012, - vol 28- No.3 - September 2013, - vol 27/ No 2 - June 2012, Susanne Wong - Vol.28/no.4 December - 2013 , Terri Hathaway - Vol. 25 / No. 4 December - 2010

$$
\text { ـ- الروابط الالكترونية }
$$

1-http://www.britannica.com/EBchecked/topic/194212/EthiopianPlateau

2-http://www.narmada.org/nvdp.dams/ 